\title{
فاعلية برامج قائم على الفنون التعبيرية لتنمية التذوق الادبي و الجمالي لطقل الروضة
}

اعداد

الباحثة / جيهان محمد الركايبي '

إشر افت

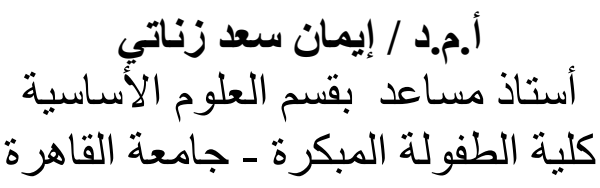

أ.د// سعاد عبد العزيز إبراهيم

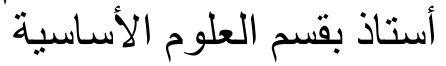

كلية الطفولة المبكرة - جامعة القاهرة الاسمة

مقدمةة :

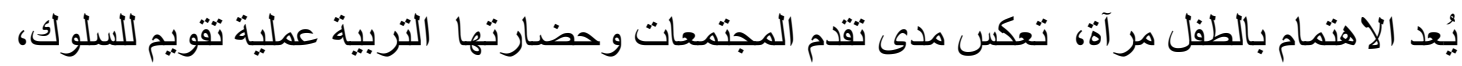

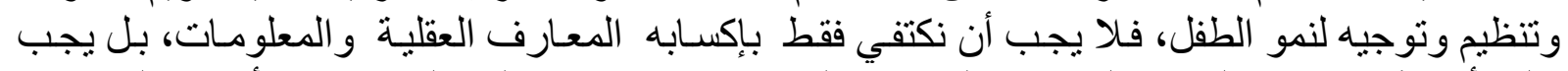

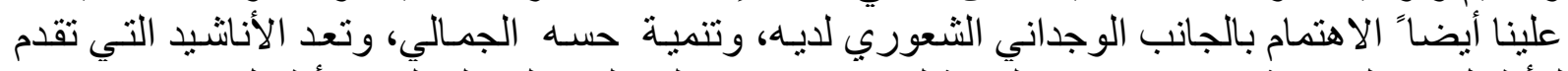

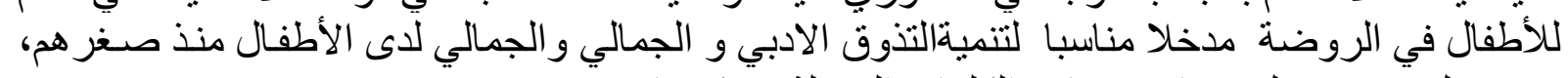

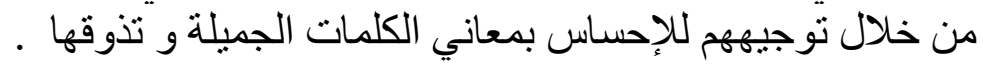

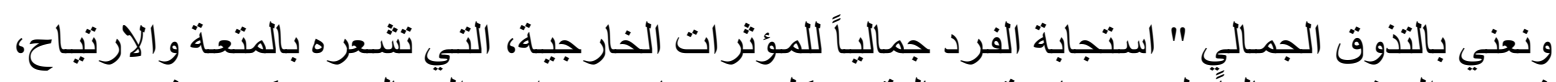

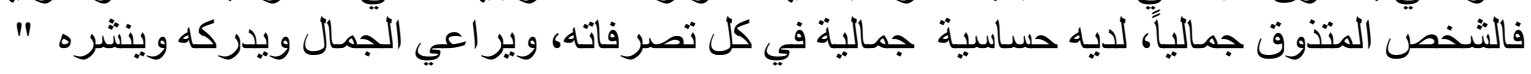
و يرتبط الطفل بالفنون البصرية و السمعية بعلاقة وثيقة ، تتعكس مباشـرة على العملية التعليمية

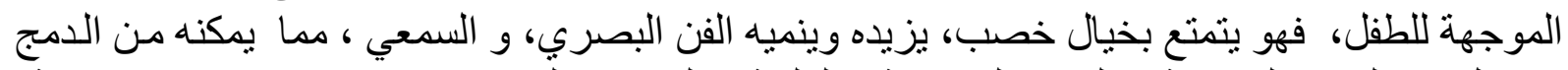

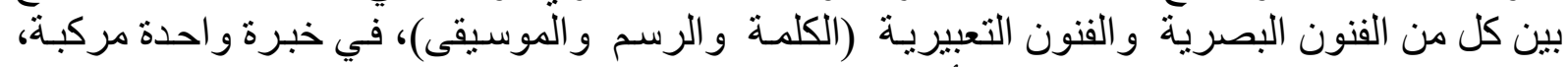

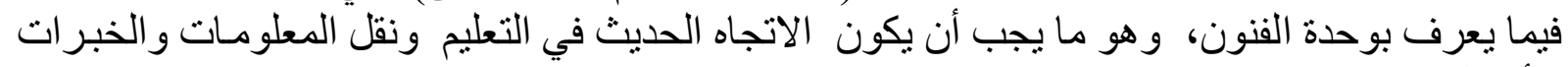

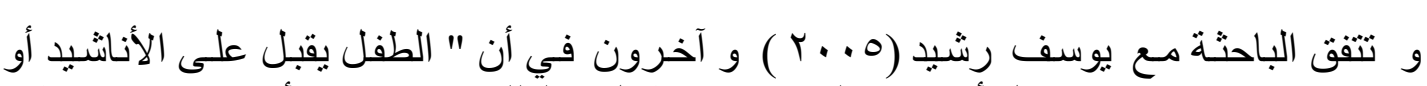

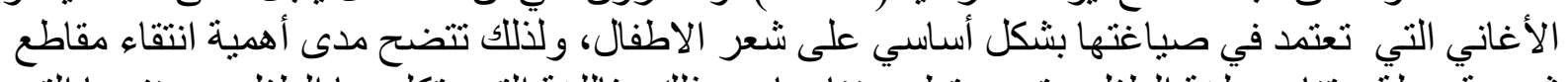

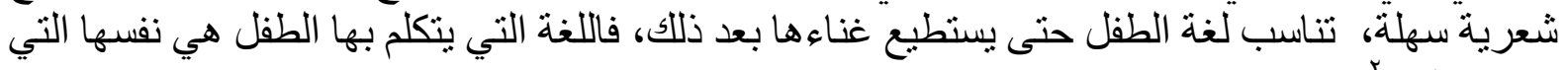

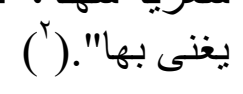

'باحثة دكتوراه بكلية التربية للطفولة المبكرة - جامعة القاهرة

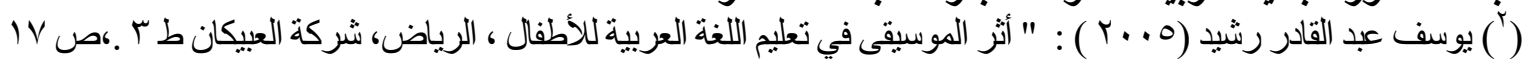

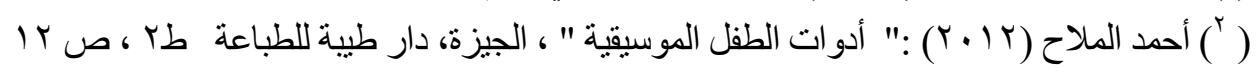




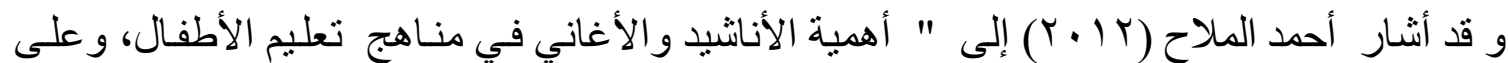

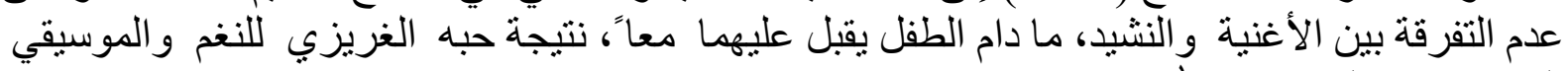

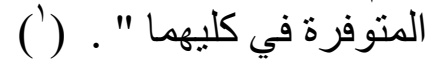

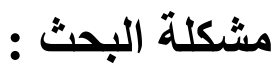

بدأ الاحساس بالمشكلة عندما كانت الباحثة تعمل موجهة رياض أطفال ، فلاحظت وجود قصور

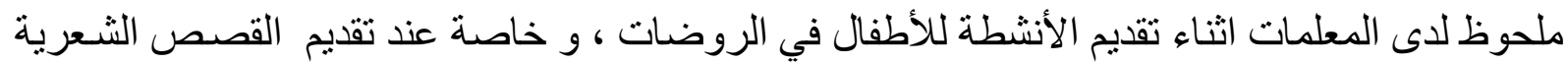

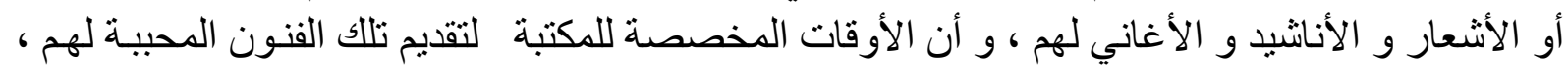

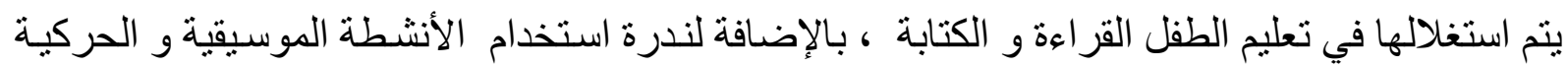

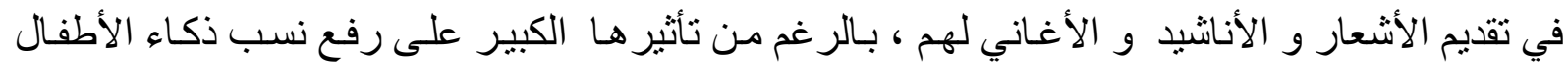

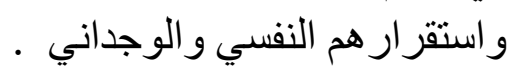

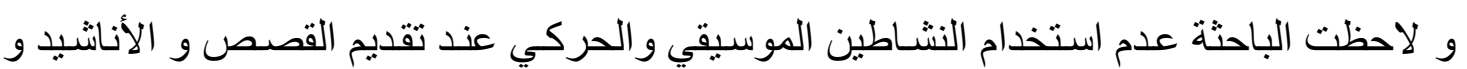

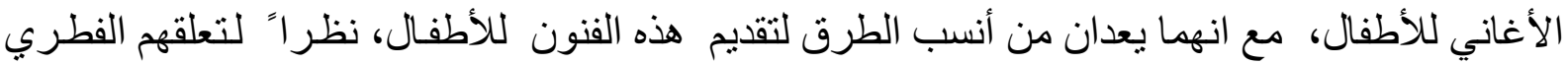

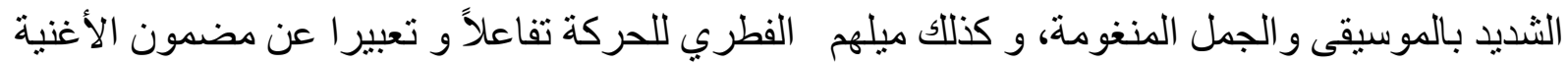

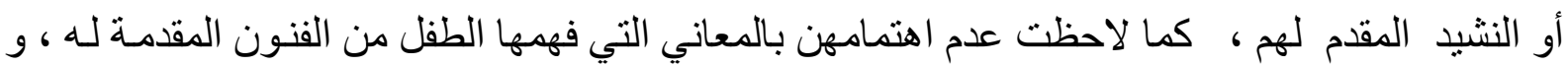

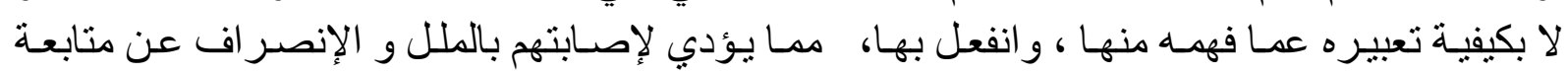

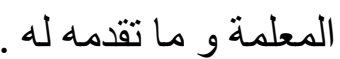

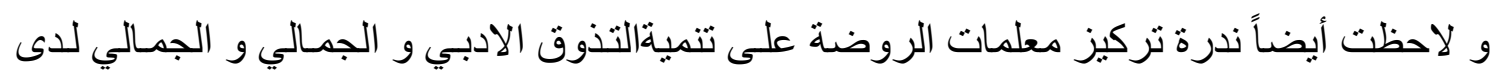

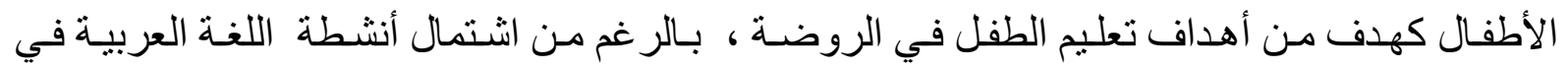

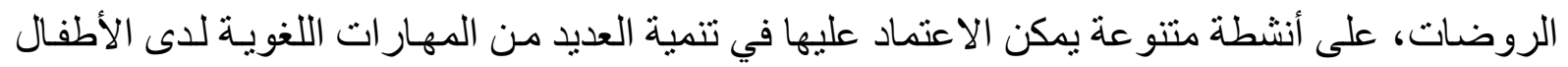

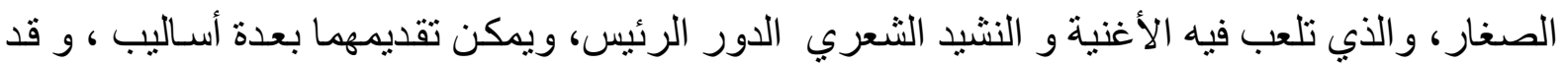

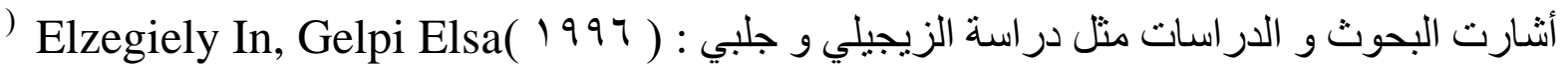

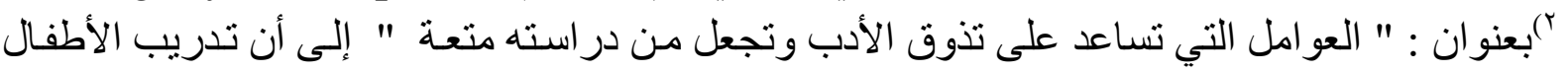

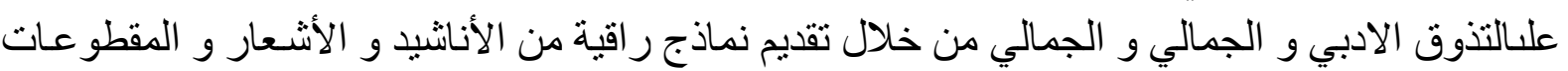

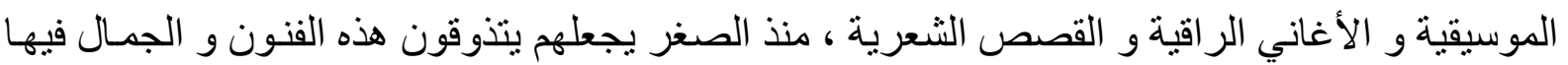

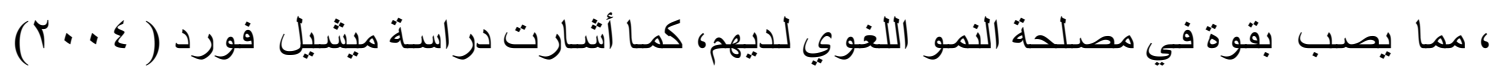

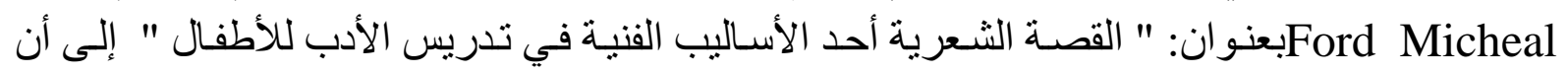

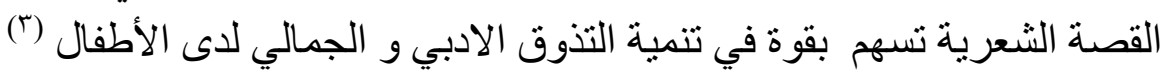

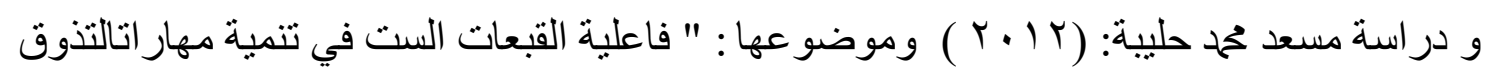

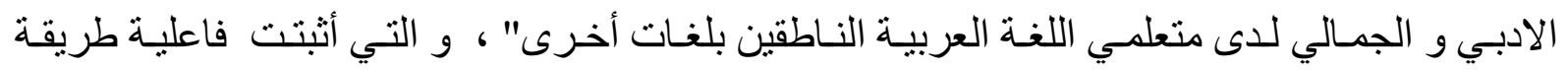

${ }^{(2)}$ Elzegiely In , Gelpi Elsa(1996) : The Enjoyment of Literature Paper, Given at the third Annual Tsol Convention Chicago, Illinois, March, Ch. 5-8, P 12 .

${ }^{(3)}$ Ford Micheal(2004) : Childrens Literature Art Activities , Art Education ,Poetry, Americans, New York , v 21, p 41- 43. 
(القبعات الست) في تنمية مهار اتالتذوق الادبي و الجمالي لدى متعلمي اللغة العربية الناطقين بلغات أخرى

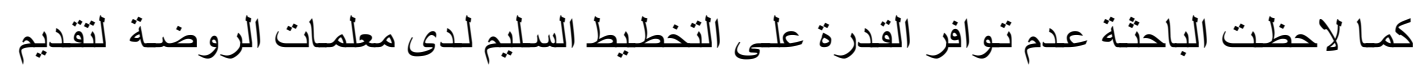

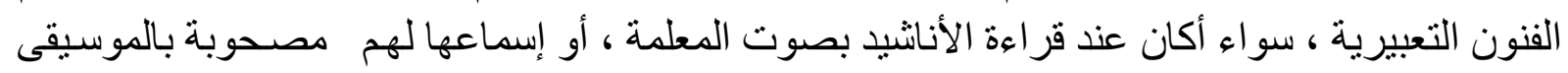

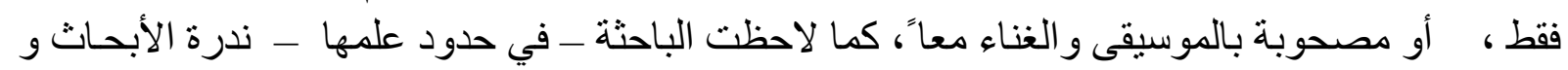

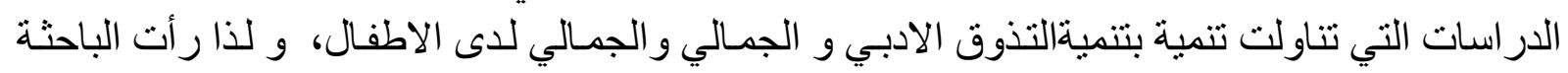

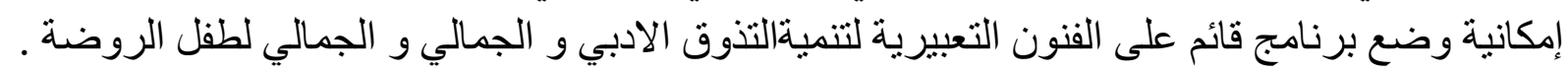

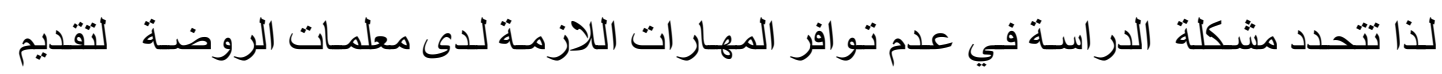

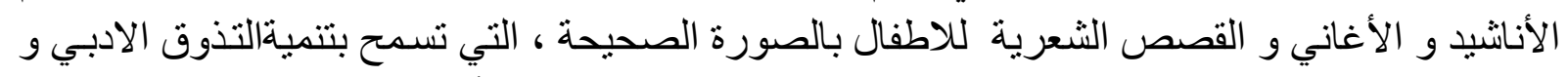

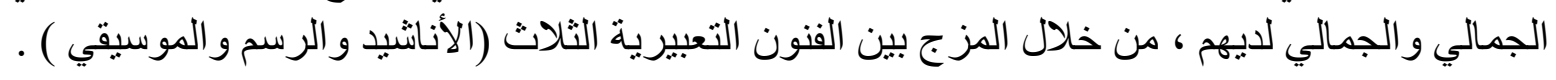

$$
\begin{aligned}
& \text { تساؤلات البحث : - ت البحث } \\
& \text { يحاول البحث الحالي الإجابة عن التساؤلات التالية : }
\end{aligned}
$$

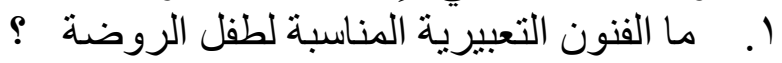

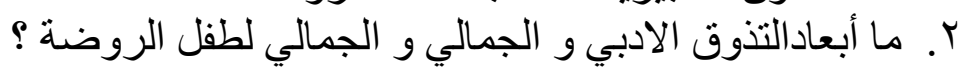

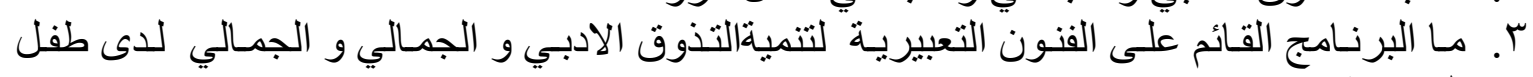

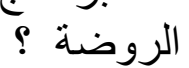

\section{أهمية البحث :- تتمثل أهمية البحث في النقاط التالية :}

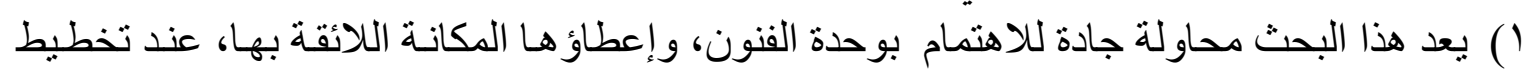

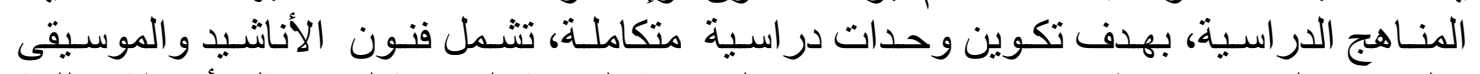

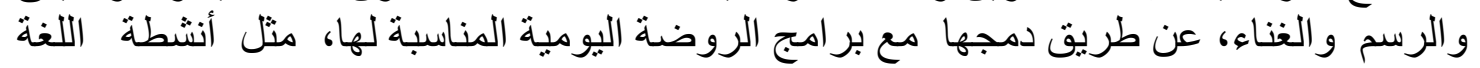

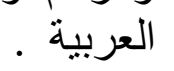

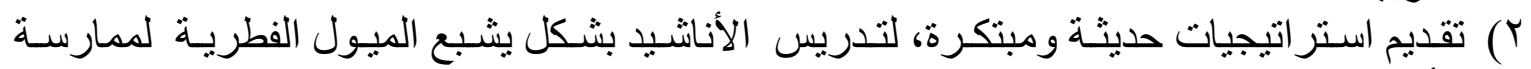

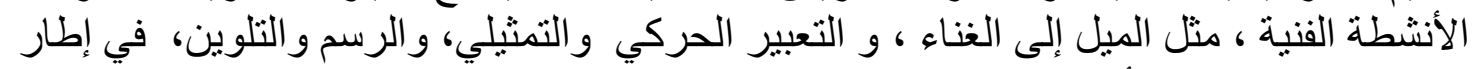

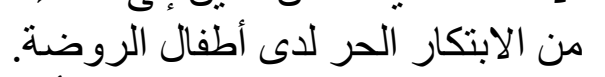

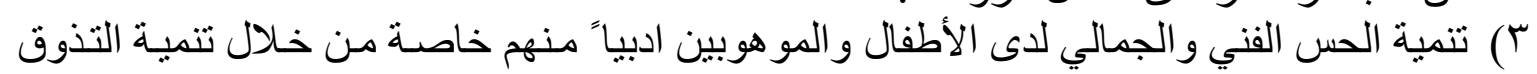

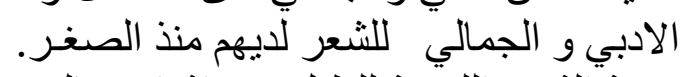

ع) تتمية الثروة اللغوية للطفل، مع إثراء خياله، وتنمية قدر اته على التذوق و الابتكار ، و ربطه بيئته

\section{أهداف البحث: يهدف البحث الحالي إلى :}

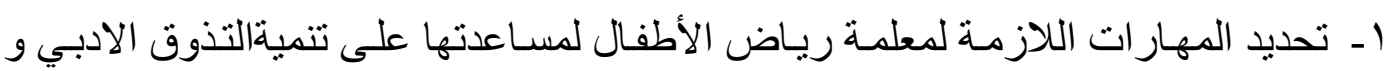

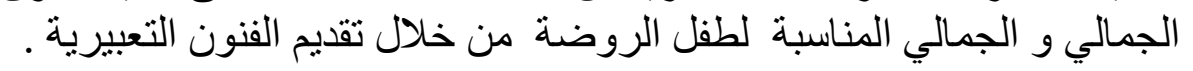

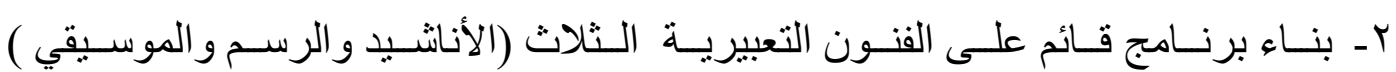

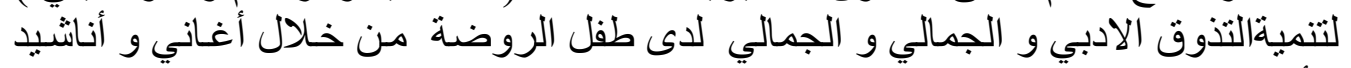
الأطفال. بـ دمـج الفنون التعبيريـة (الأنانتيد و الرسم و الموسيقى) في وحدة در اسية واحدة ، عند تدريس الاناثيد في بر امجية الروضة.

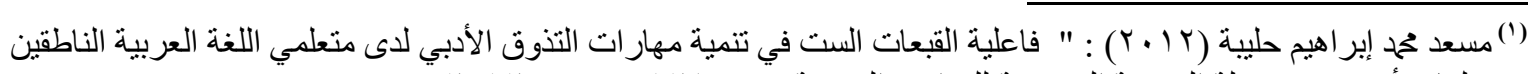

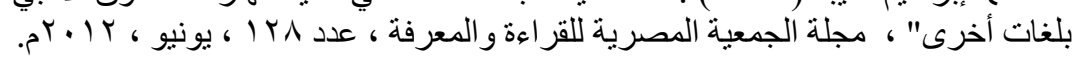


فروض البحث : مترو

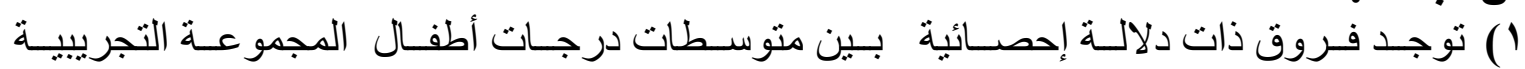
(عينةالدر اسة) فى القياسين القبلي والبعدي على أبعاد اختبار مقياس التذوق الأدبي و الجمالي لطفل

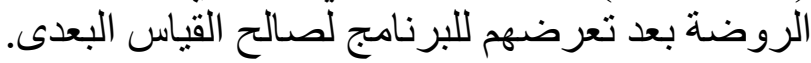

ץ) توجد فروق ذات دلالة إحصائية بين متوسطات درجات أطفال المجموعة التجريبية

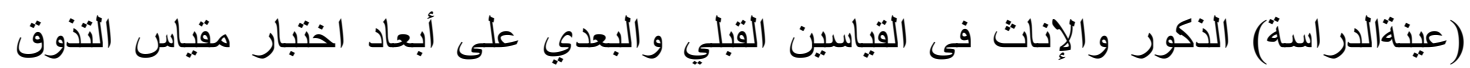

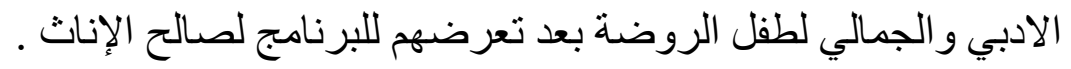

حدود البحث : - الحدود البشرية : يقتصر البحث على عينة عددها ( ـ ج) طفلاً وطفلة) للقياسين القبلي

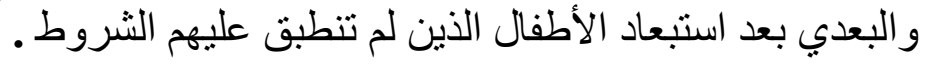

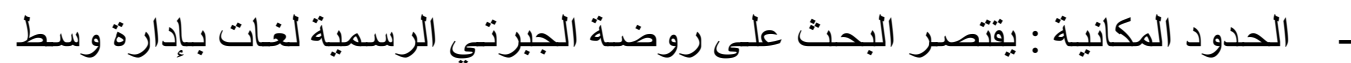

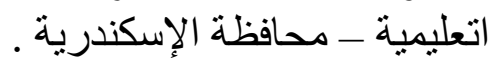

- الحدود الزمانية : يقتصر البحث على ثثلاثة أثهر بمعدل ثناثة أيام في الأسبوع .

منهج البحث : اعتمدت البحث الحاليعلى المنهج التجريبي التصميم ذو المجمو عة التجريبية الو احدة .

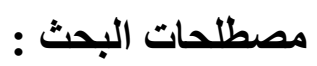

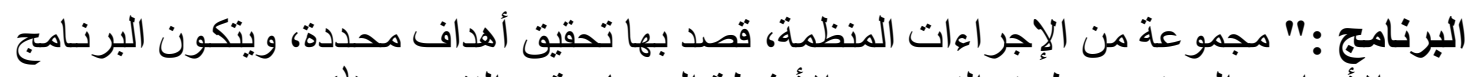

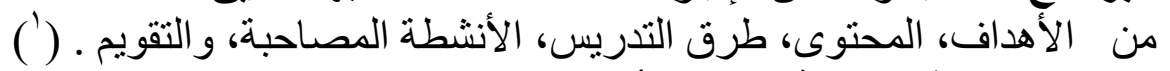

O م تعرفه الباحثة إجرائيا بأنها :

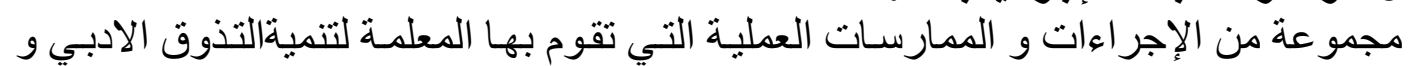

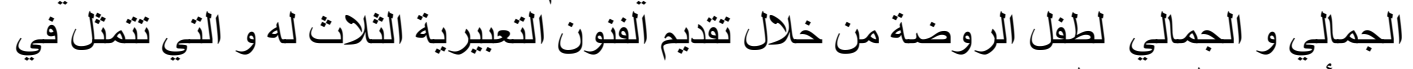
(الأناثيد و الرسم و الموسيقي ) :

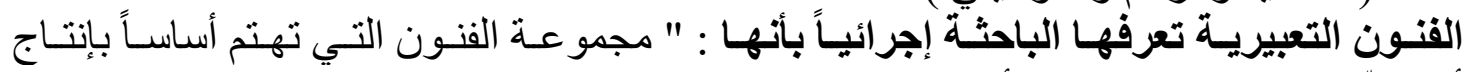

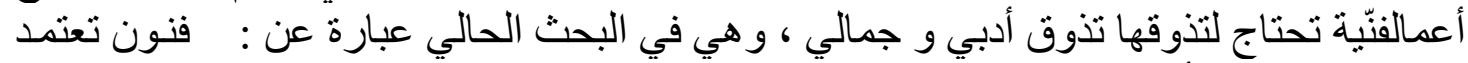

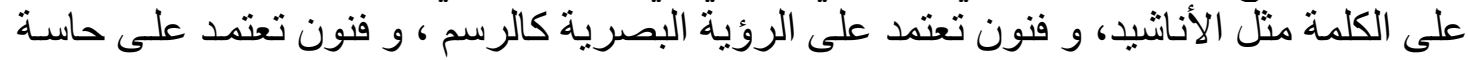

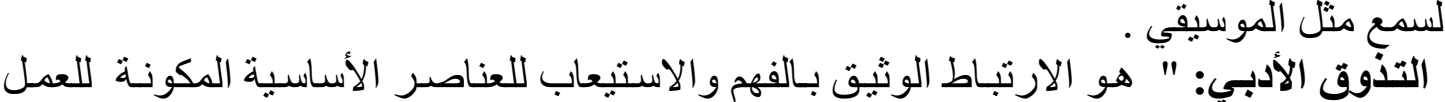

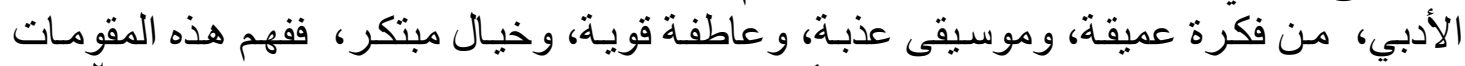

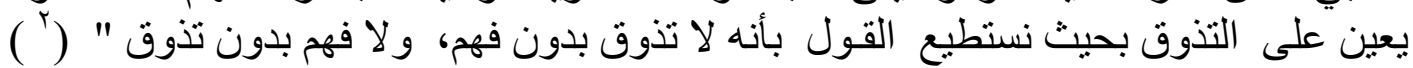

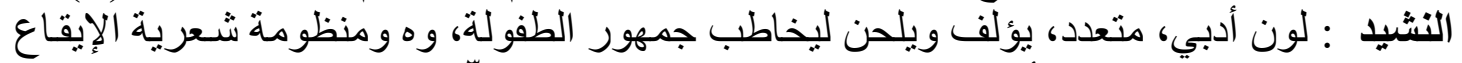

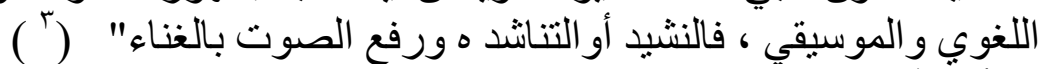

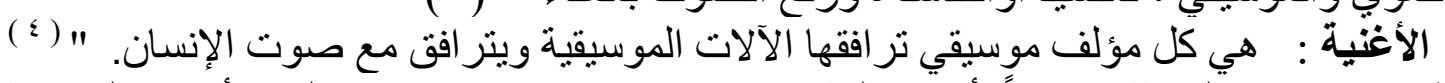

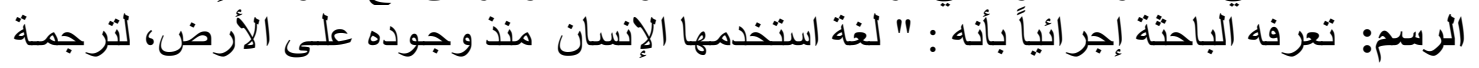

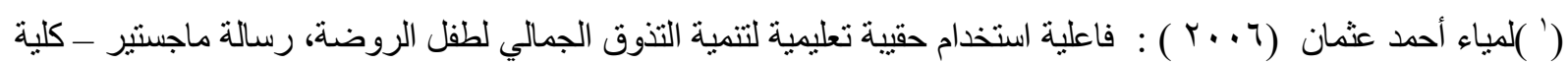
رياض الأطفال - جامعة الاسكندرية.

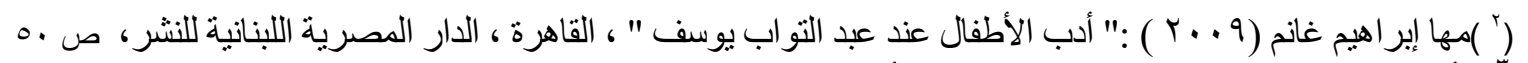

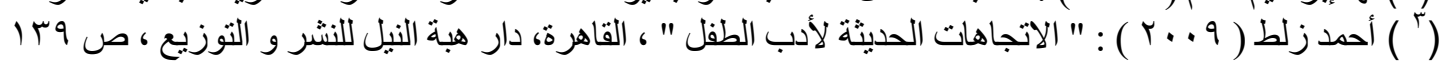

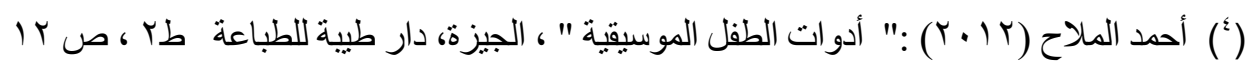


المشاعر التي يشعر بها، بشكل ابتكاري، ليحقق بها غايات وأهداف هامة في حياته " .

إطار النظري ودراسـات سابقة:

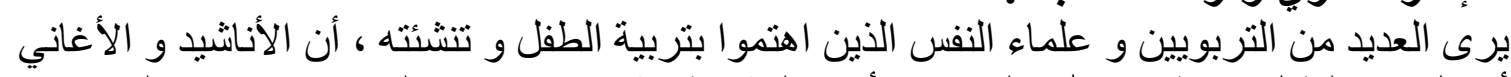

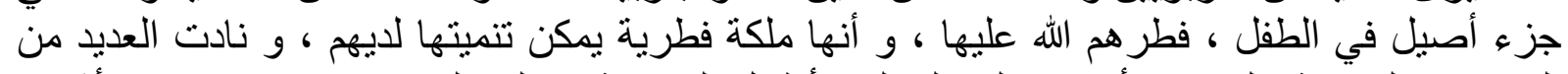

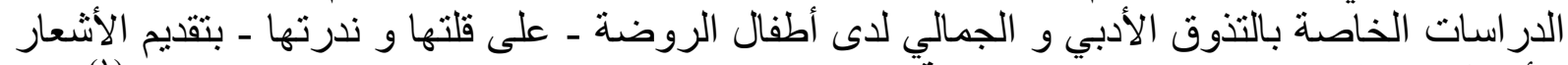

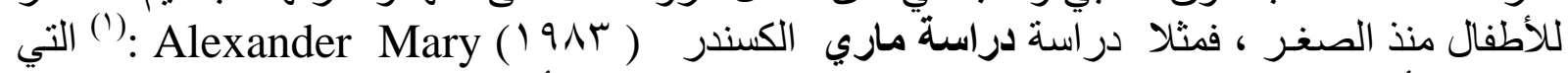

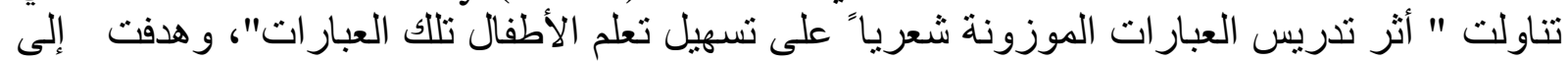

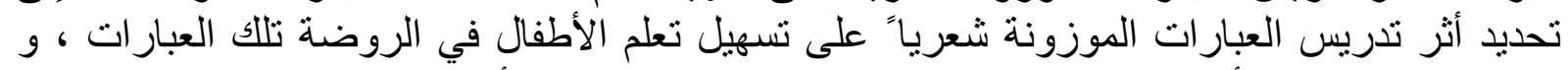

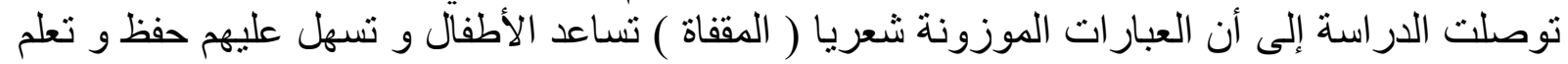

وقا استفادت الباحثة من هذه الدر اسة في التأكد من أن العبار ات الموزونة شعريا ( المقفاة ) تلاك العبار ات.

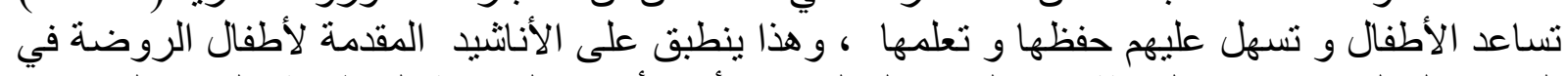

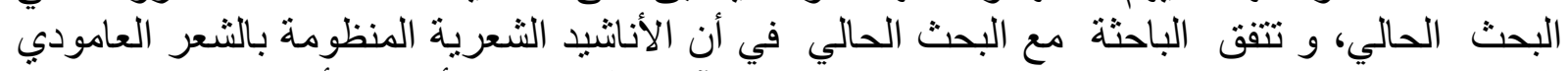

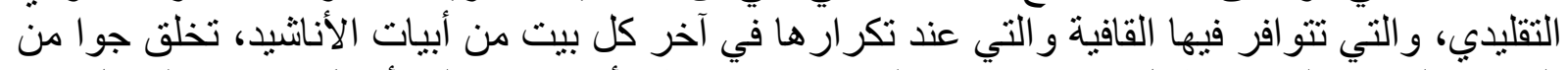

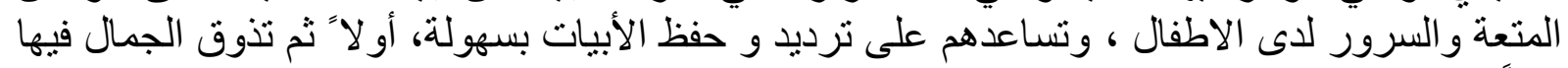

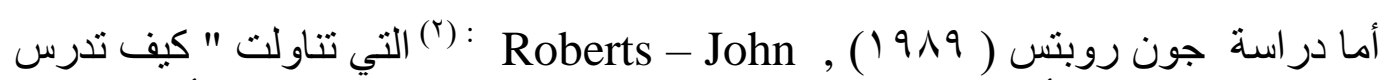

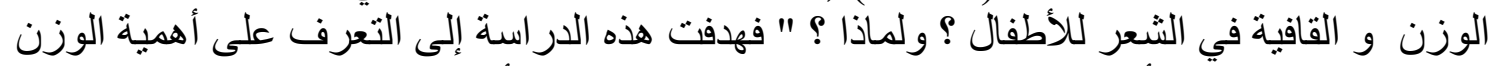

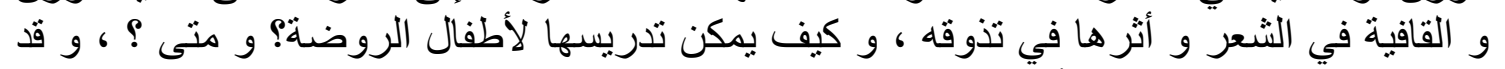
وتوصلت الآدر اسة إلى نتائج أهمها:

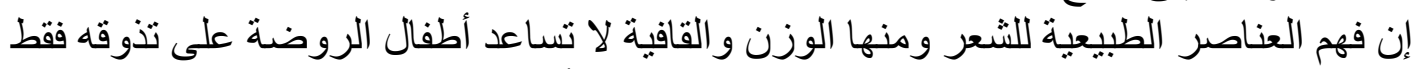

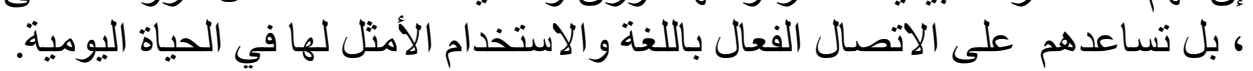

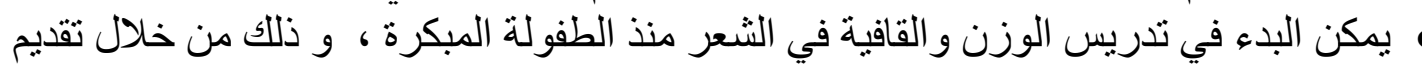

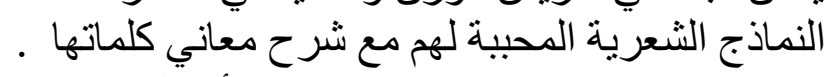
يساعد وجود الوزن والقافية في الثعر أطفال الروضية على حلى حب القصيدة ، و تذوق جمالها ، و سهولة حفظها .

غناء الاناثيد ملحنة بلحن سريع و خفيف يساعدهم على الاتصال الفعال باللغة، وفي

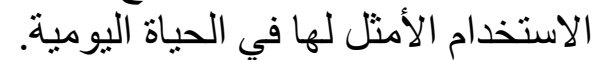

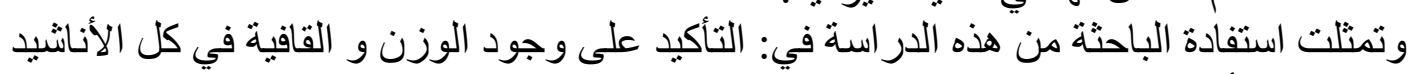

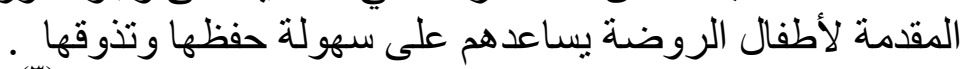

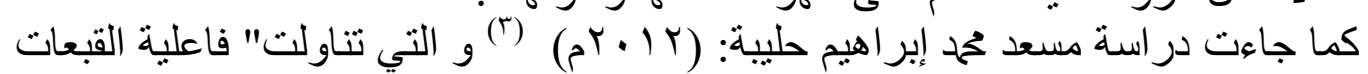

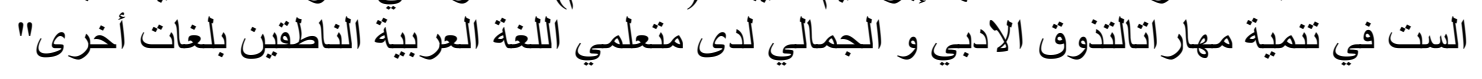

و هدفت إلى التعرف عن مدى فاعلية طريقة (القبعات الست) في تتمية مهار ات التذوق الادبي و

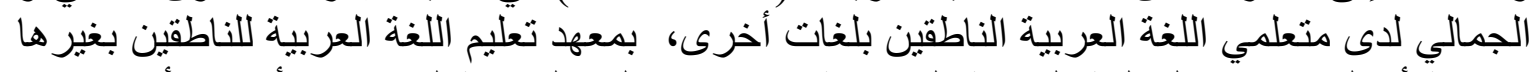

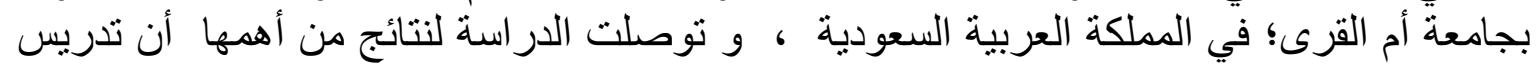

(1) Alexander Mary, E.D.D( 1983) : The Influence of Rythming Vrses on Young Children Ability to Repeat Rhythmic Phrases, North Texas State University, p. 30.

${ }^{2}$ Roberts - John, : Teaching Meter (1989) ,Why and How ? Paper Presented at the Annual Meeting of the National Conical of Teachers of English , $69^{\text {th }}$, son Francisco 22-24 ( p . 28 )

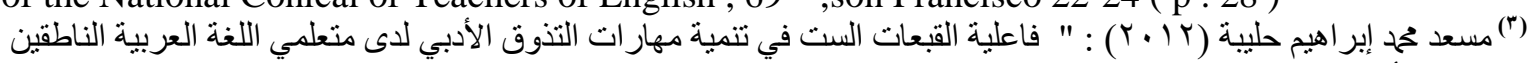

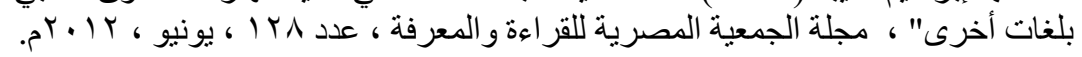




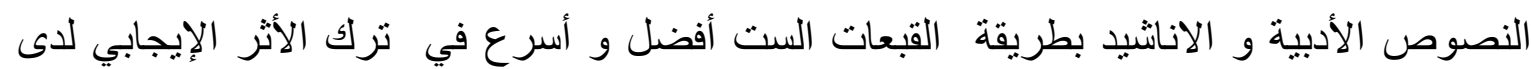

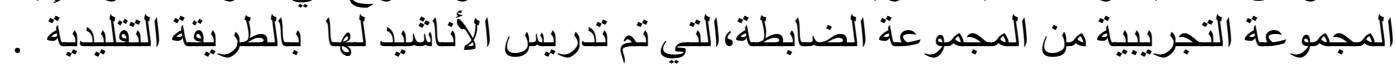

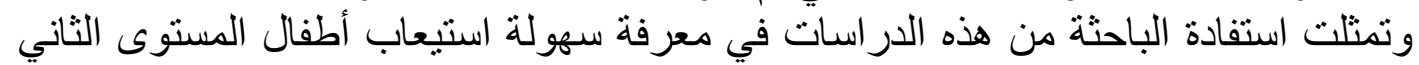

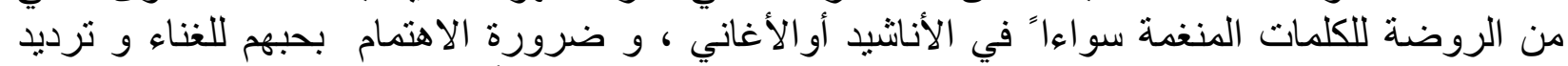

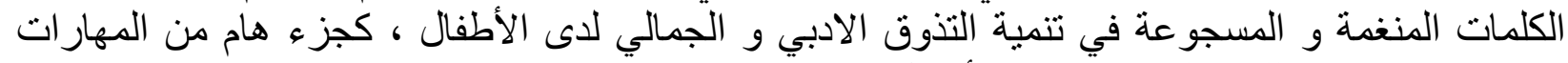

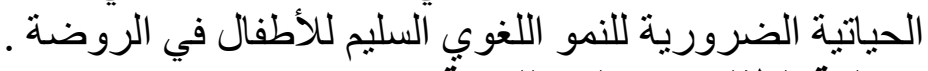

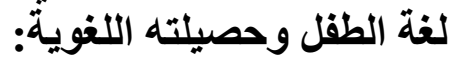

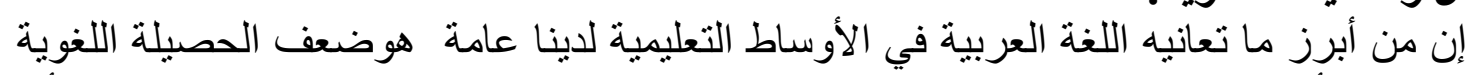

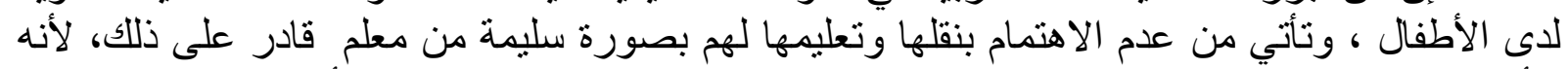

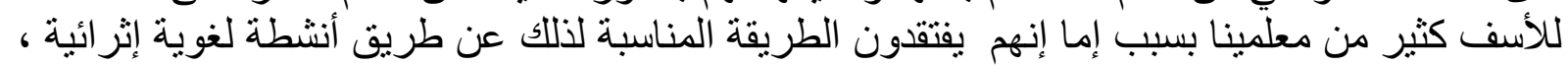

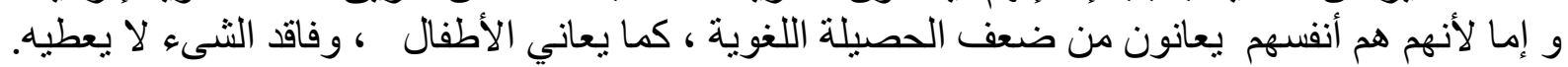

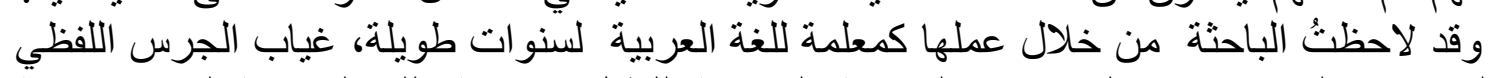

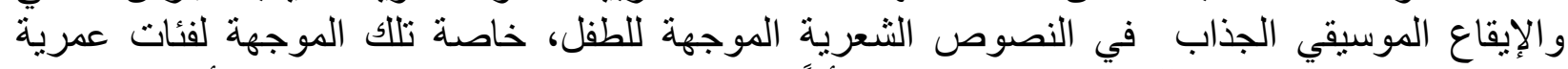

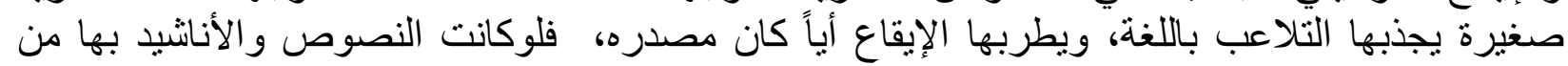

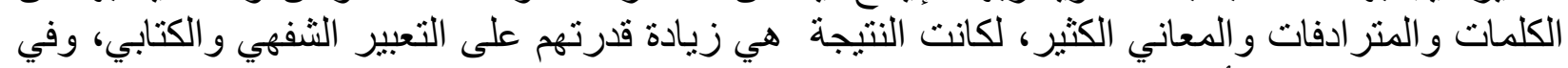

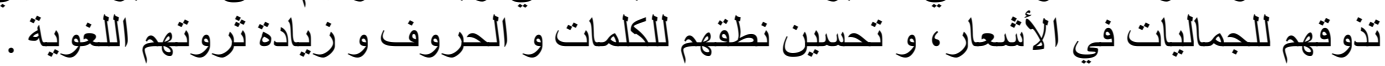

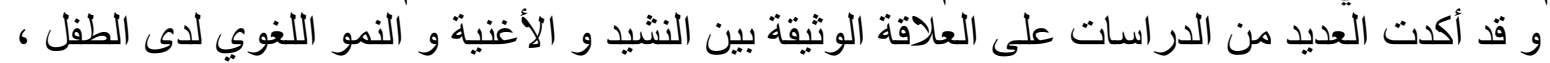

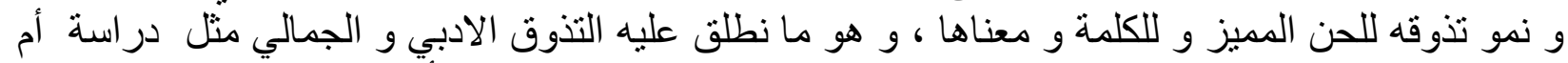

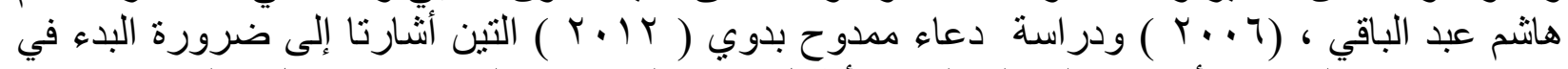

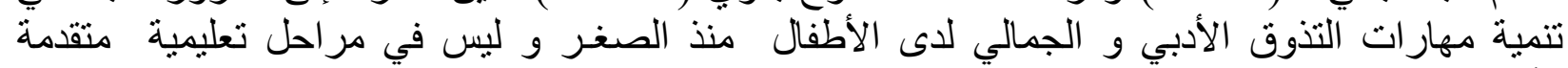

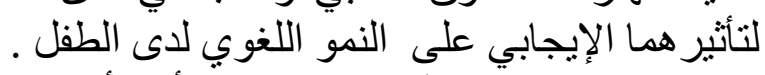

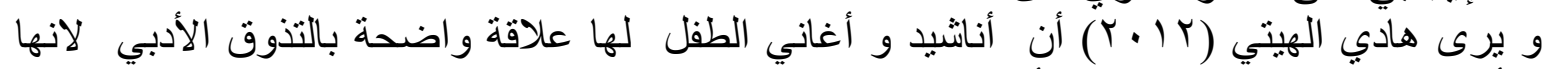

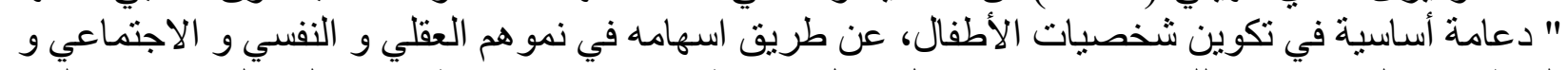

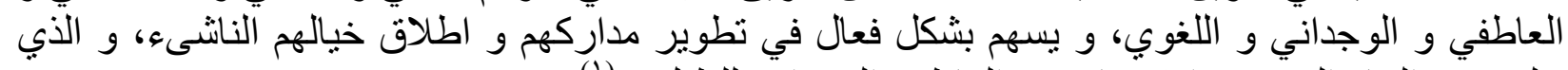

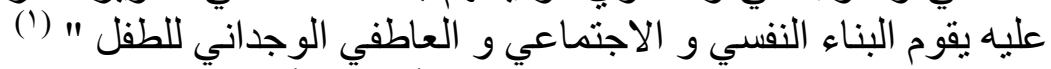

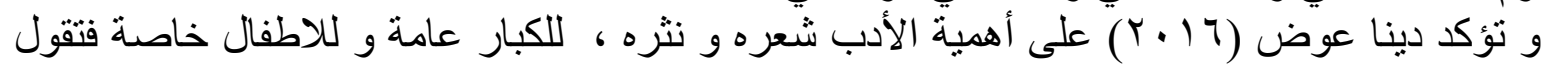

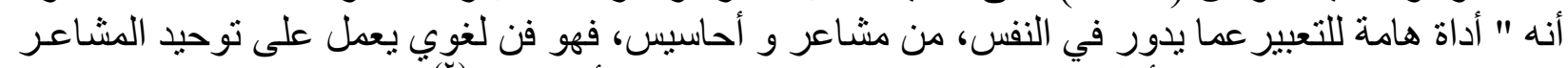

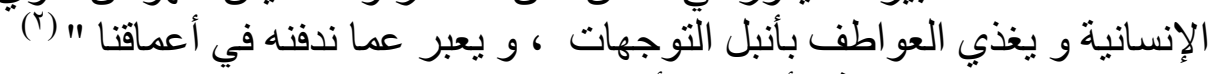
العروض الموسيقي في أناشيد الأطفال : العنات

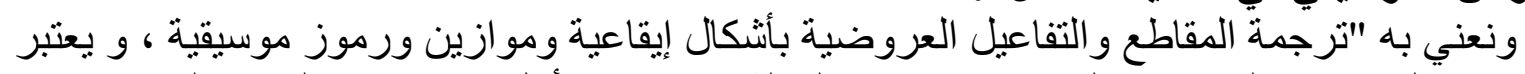

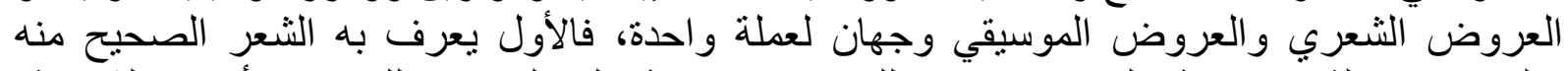

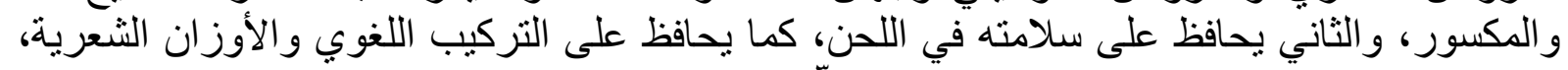

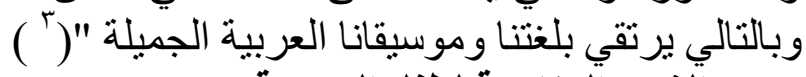

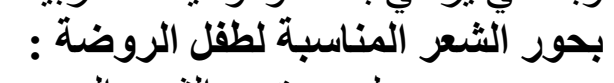

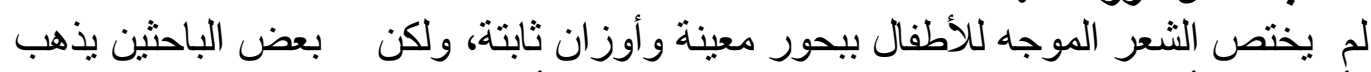

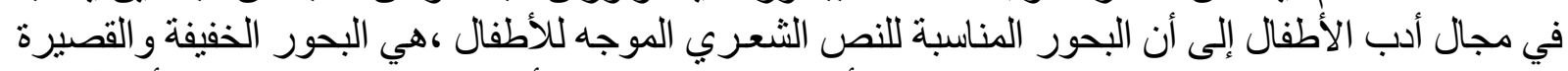

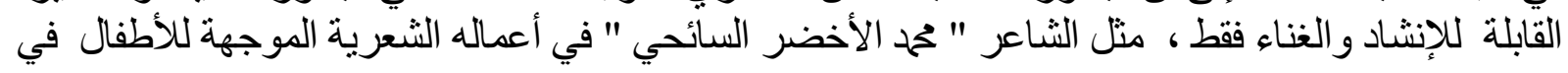

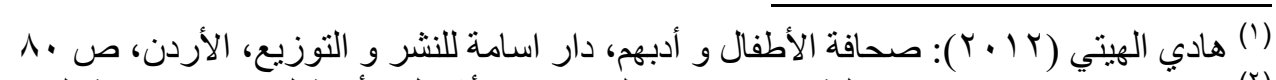

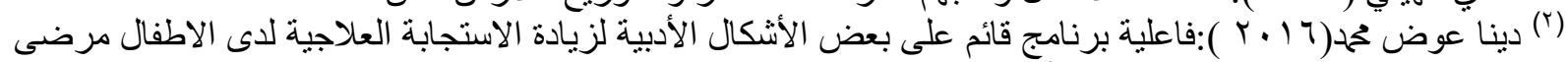

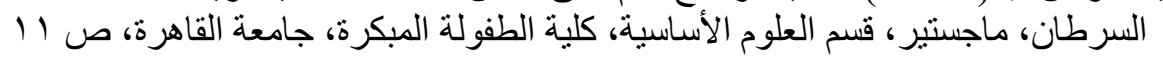

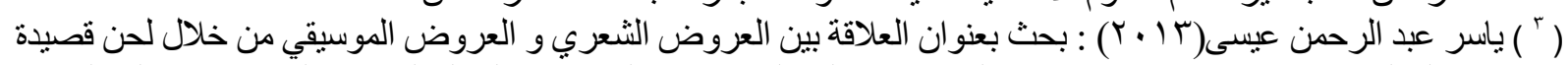

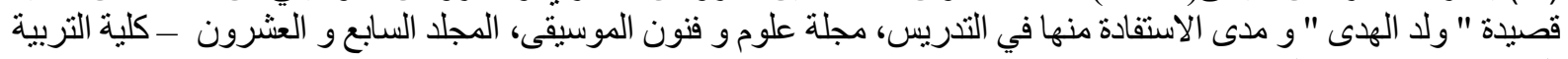

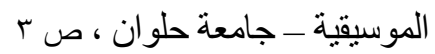


ديوانه "أناثيد النصر" الذي فضل استخدام البحور الخفيفة، ومال إلى المجزوءات ف فقط ، لأنها تصلح

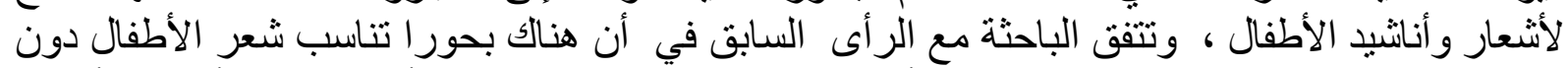

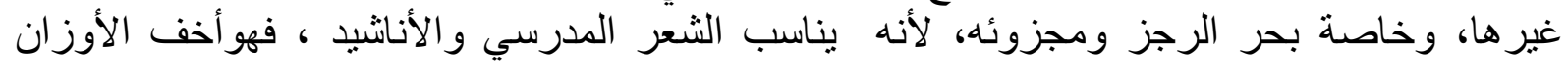

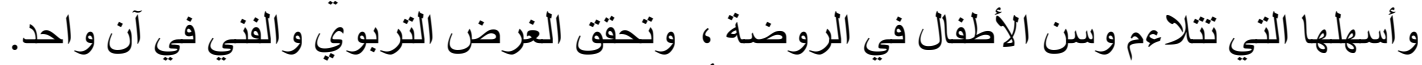

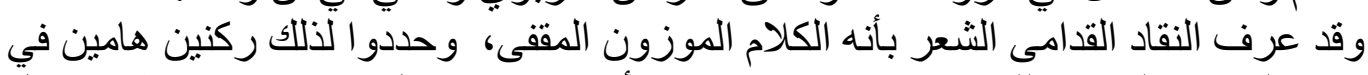

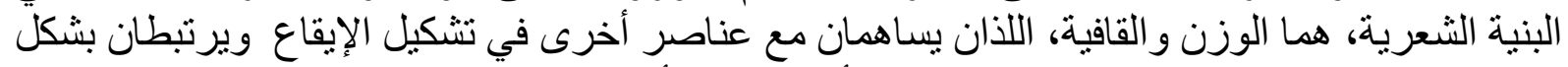

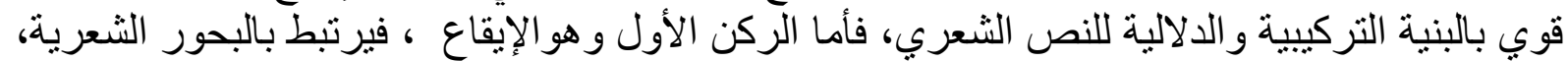

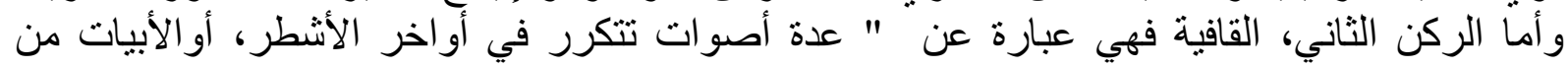

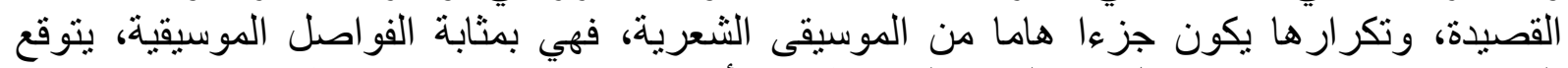

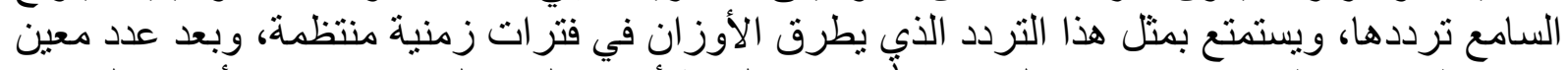

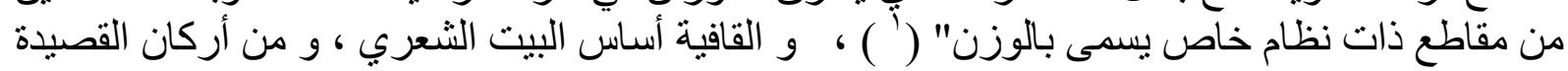

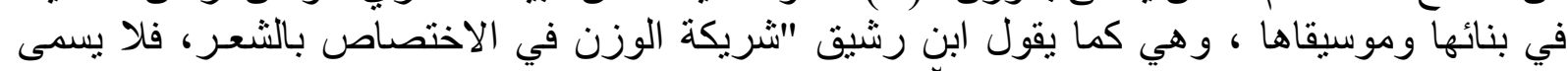

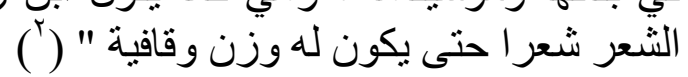

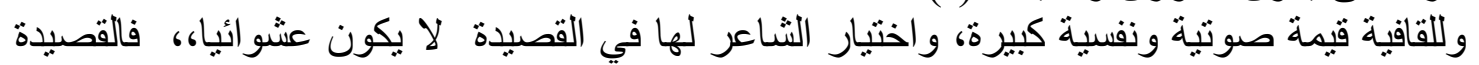

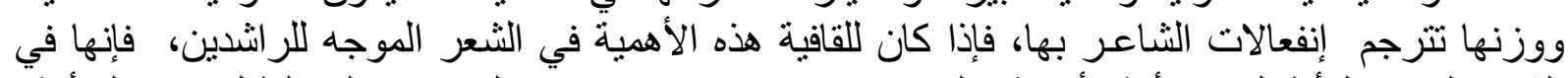

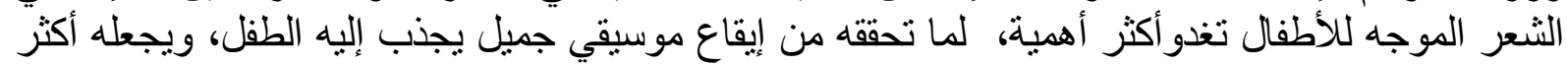

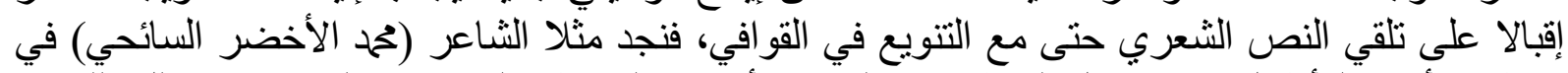

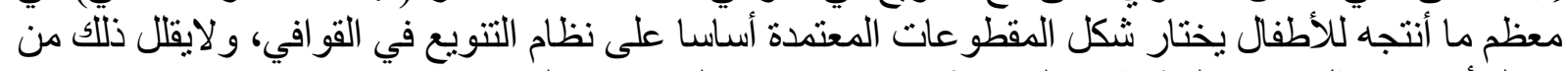

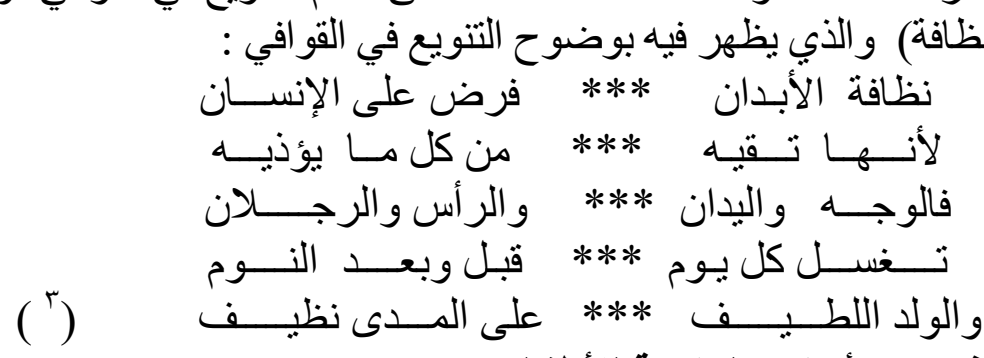

\section{خصائص الأغاني والأناشيد المقدمة للأطفال :}

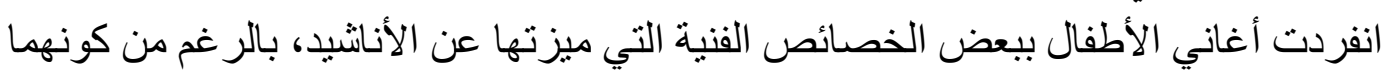

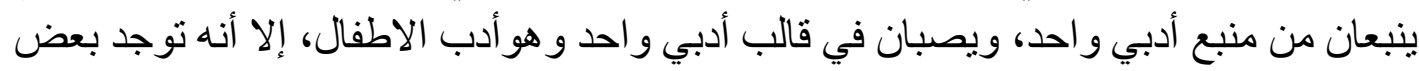

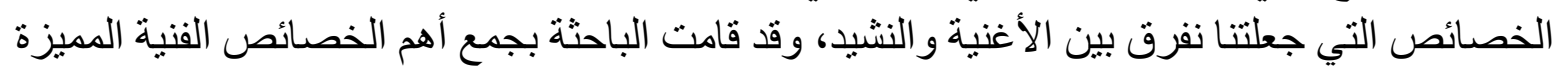

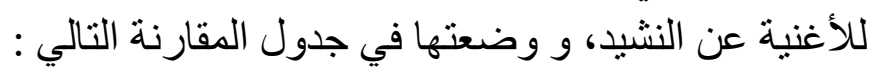

(') إبر اهيم أنبس (1999 ): موسيقى الثُعر ، القاهرة ، مكتبة الأنجلو الأمريكية، طץ ، ص 19

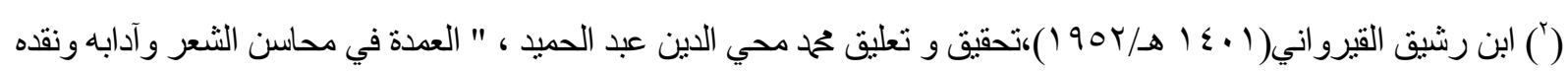

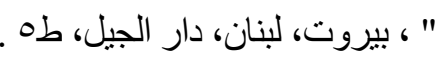

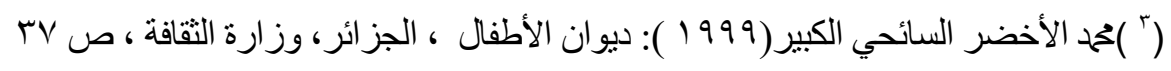




\begin{tabular}{|c|c|c|}
\hline خصائص نشـيـــ الطقل : & خصائص أغنـــة الطقل: & r \\
\hline بدأ منتأخر اً مع بداية ظهور الحضار ات و الثقافات & 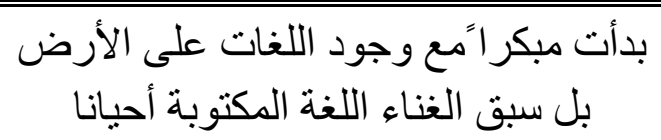 & 1 \\
\hline يدخل عالم الطفل مع بداية الحضانة أو المدرسة & تغنيها الأمهات للأطفال من لحظة الميلاد & $r$ \\
\hline يخاطب النشيد الفئة المقدم لها بخصائصها اللغوية & 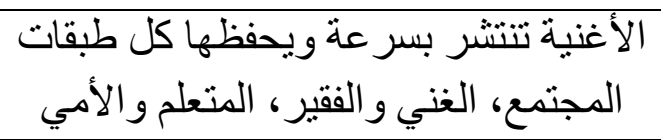 & $\mu$ \\
\hline يحتمل الصورة الشعرية، و الصور الكلية & 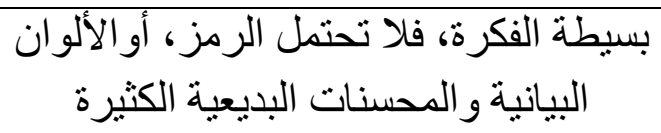 & $\varepsilon$ \\
\hline لا يفضل الإلقاء السريع للنشيد، فيفسده ويقلل جماله & يتسم طابعها بالخفة والإيقاع السريع & 0 \\
\hline يمكن تقديم الأناشيد بغير مصاحبة الموسيقى. & لا يمكن تقديم الأغاني بكل أنو اعها بغير & 7 \\
\hline يفضل استخدام اللغة العربية الفصحى في كلماته & يفضل فيها استخدام العامية الخاصة بكل بلد & $\mathrm{V}$ \\
\hline يقدم النشيد بطريقة الإلقاء الشعري أومن خلال & تتعدد أثنكال تقديم الأغنية مثل الأوبريت، الغناء الأوبر الي، والغناء الكور الي. & $\Lambda$ \\
\hline
\end{tabular}

\section{أهمية الأناشيد و الأغاني للأطفال:}

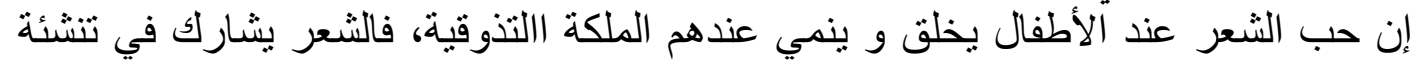

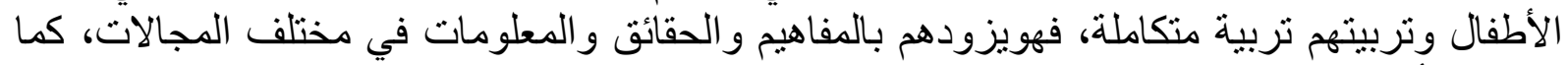

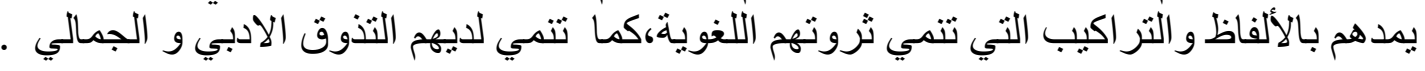

\section{الأهداف التي يمكن تحقيةها من تقديم الاناشيد الشعرية للأطفال في الروضة :}

نستطيع من خلال شعر الأطفال الجيد، الذي يحمل في طياته رسائل تربوية وأخلاقية وجمالية، في

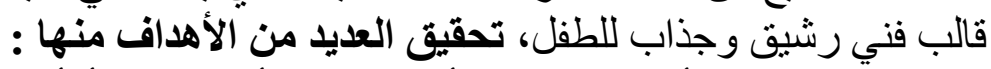

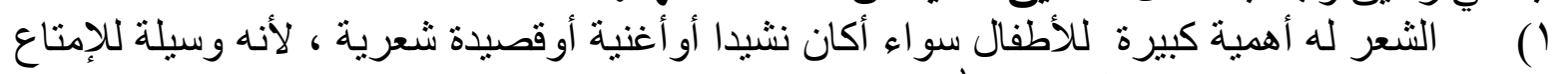

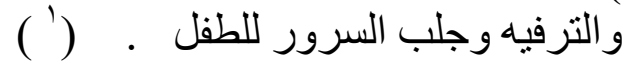

الثعر بعمل بشكل أساسي على تتميةالتذوق الادبي و الجمالي لدى الطفل، ويدربه في سن صغيرة

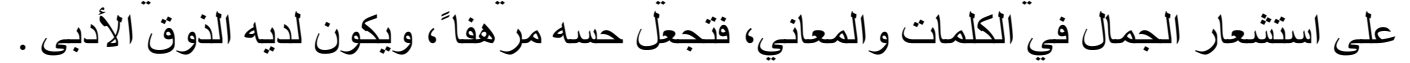

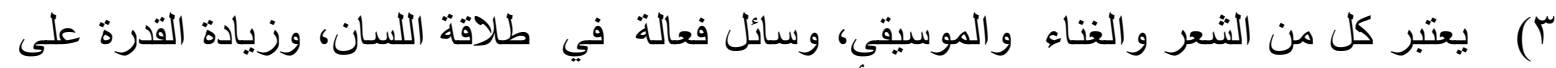

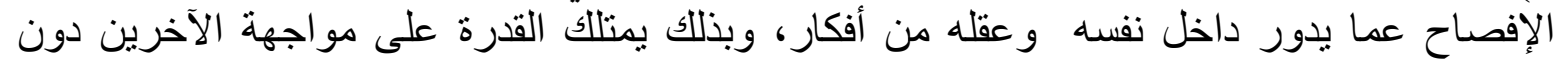


الثعر يسهم بشكل فعال في التربية الوجدانية للطفل، وينمي بشكل مباثر حبه للجمال وتقديره له .

و ترى الباحثة أن الأناثيد يمكنها تحقيق الأهداف التالية للطفل :

* الامتاع و التسلية. * تنمية الخيال و القدرة علي الابتكار. * تنمية التذوق الفني و الحسي لدي الاطفال.

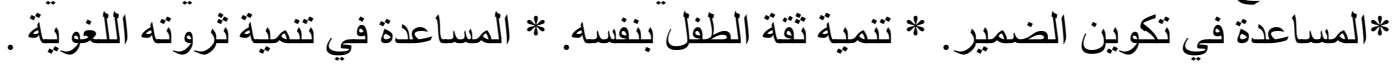

\section{المقاييس والمعايير المحددة للأناشيد المقدمة لأطفال الروضة :}

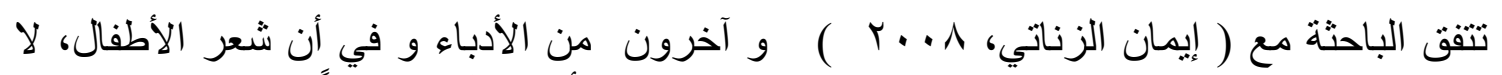

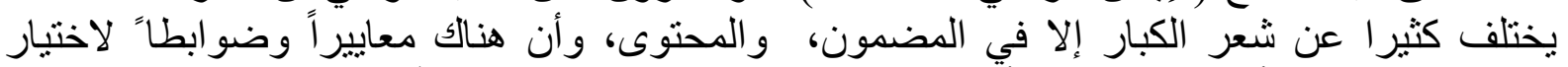
الثعر و الأناثيد المقدمة الأطفال الروضية، نذكرها في النقاط التالية :

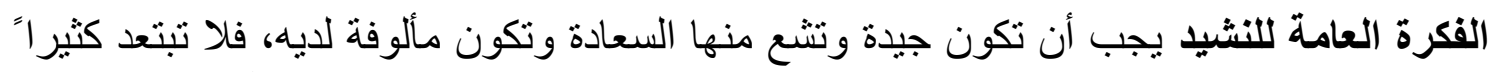

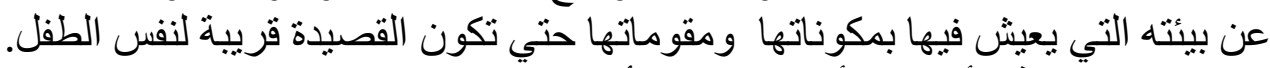

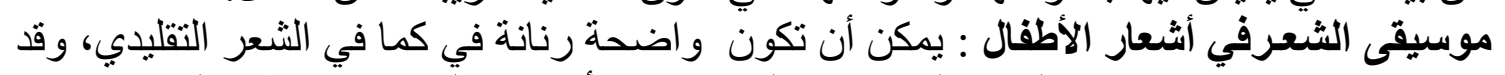

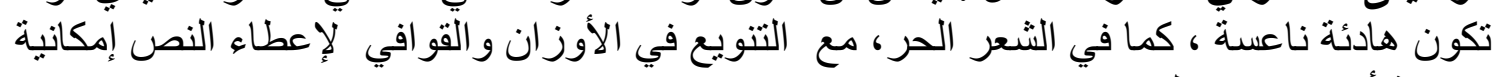

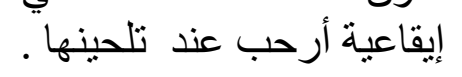

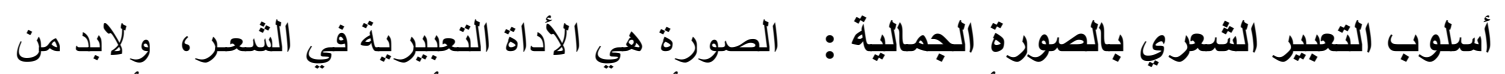

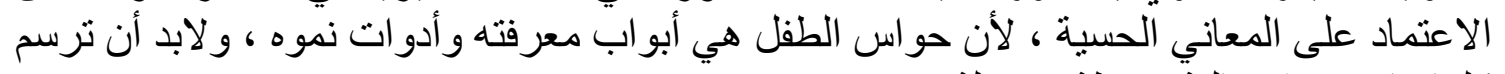

$$
\text { كلماتها صور الخيالية بسيطة وجميلة. }
$$

و يتضح مما سبق ضرورة تقديم الأناثيد بكافة أنو اعها للأطفال ، لأنها تشجعهم على التذوق

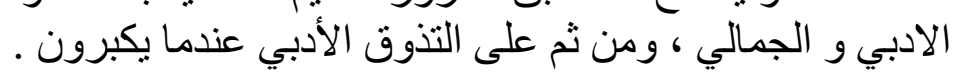

استخدامات أناشيد و أغاني لأطفال على المستوى التعليمى :

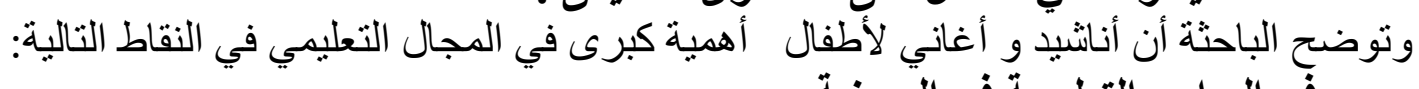

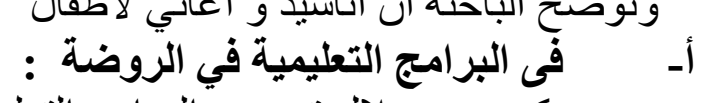

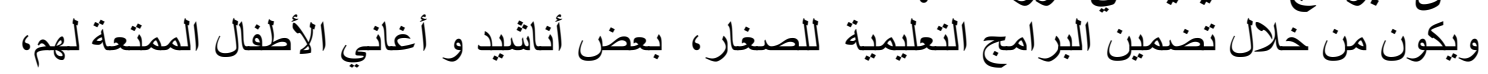

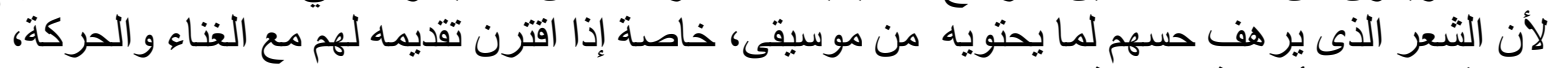

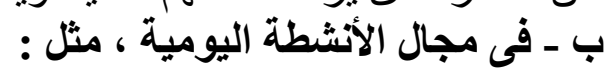

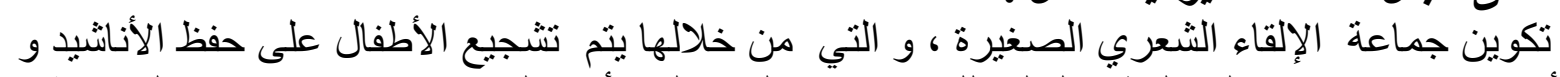

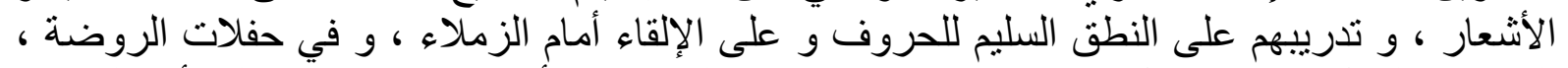

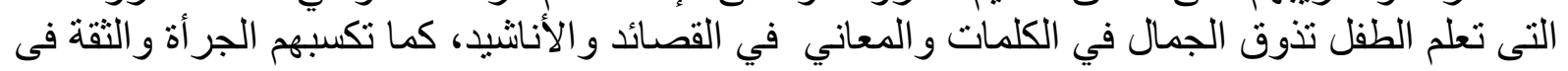

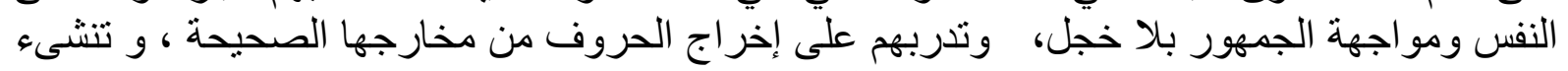
علاقة قوية بينهم و بين النشعر و اللغة منذ الطفولة .

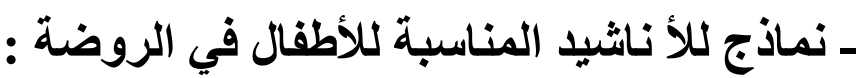

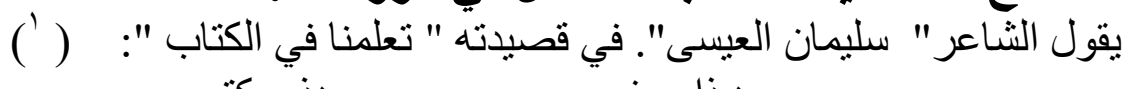

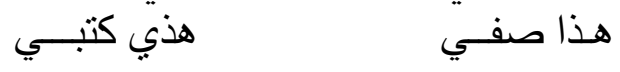

$$
\text { ' سليمان العيسى (1999) : ديوان الاطفال دشق ، دار الفكر ، ص } 10
$$




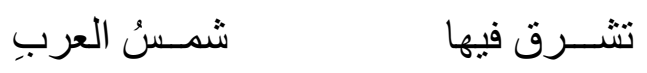

كتاب حاول فيه توضيح أثر الموسيقى في تعليم الأطفال اللغة العربية ، وقد تم تلحين بعضها مثل نثيد )

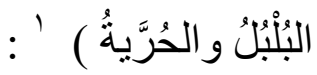

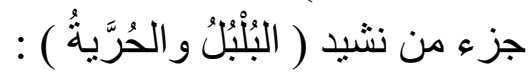

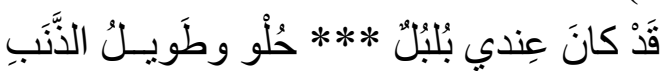
أَنْكنتُشُهُ في حُجْرَتي *** في قَفَص منْ ذَهَب

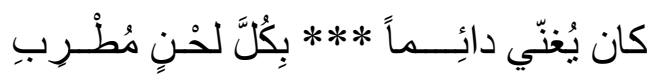

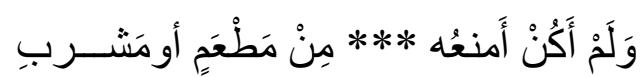

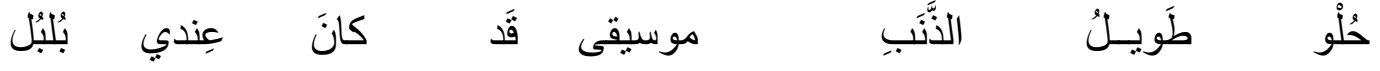

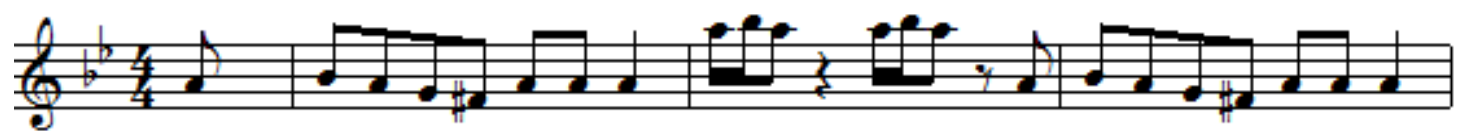

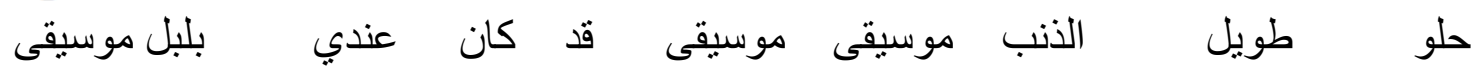

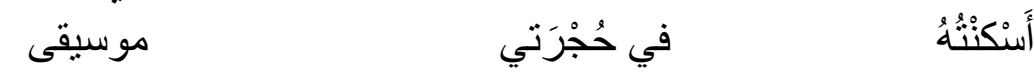

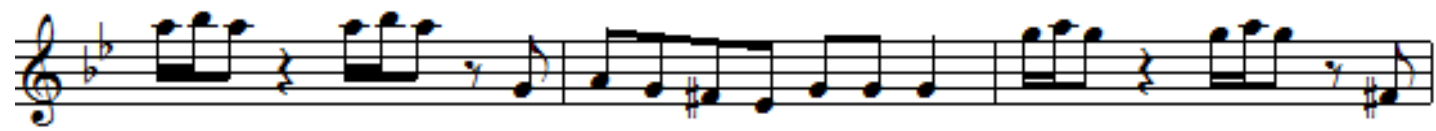

كان يُغنّي

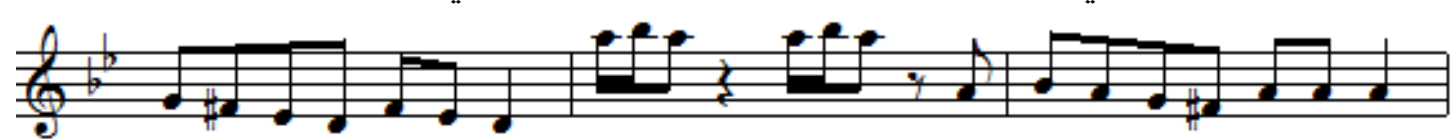

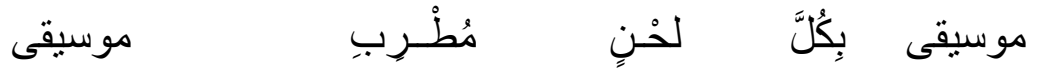

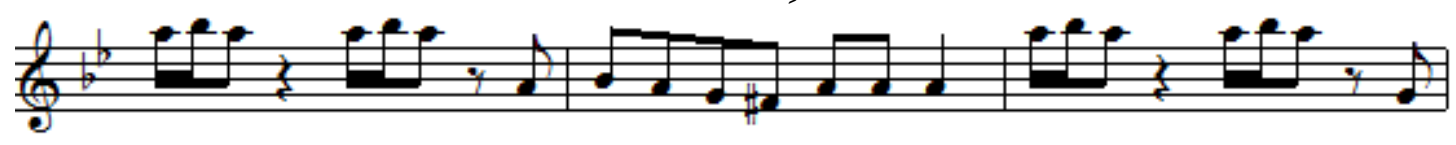

$\left.{ }^{r}\right)$

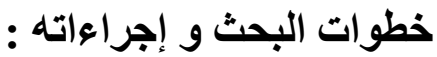

أولا : منهج البحث : استخدمت الباحثة المنهج التجريبي لمناسبته لطبيعة هذا البحث ، و ذللك باستخدام

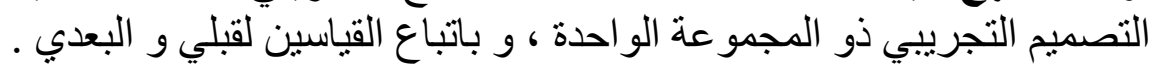
ثانيا: مجتمع و عينة البحث :

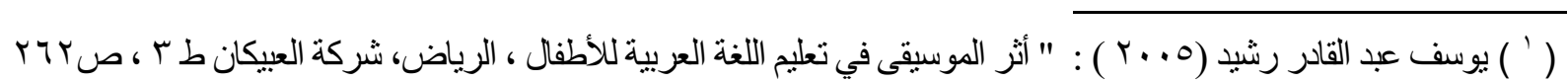

( ) اللحن للدكتورة سعاد عبد العزيز إبر اهيم ، أستاذة الموسيقي في كلية التربية للطفولة المبكرة - جامعة القاهرة . 


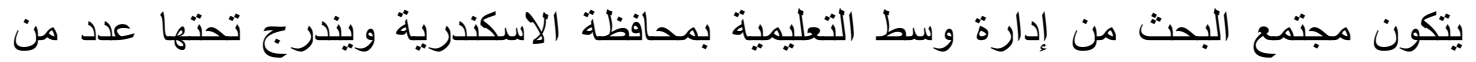

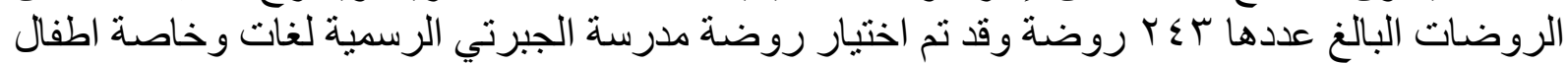

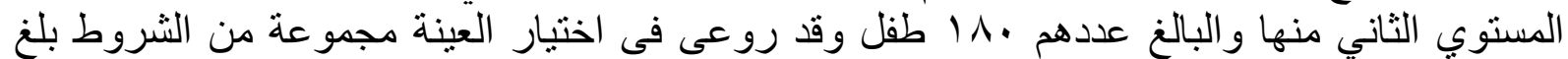

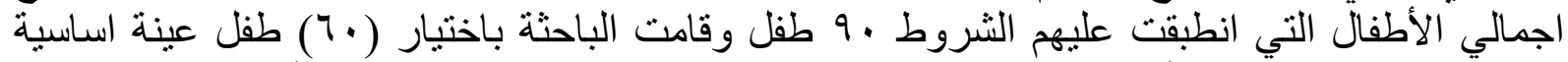
و استعانت بـ (• (؟) طفل أخرين فى الدراسات الإستطلاعية والمعاملات العلمية للأدوات وقات وقد انبطقت عليهم الثروط الآتية: - - ارتفاع نسبة الذكاء. - - التقارب المستوي الاقتصادي و الاجتماعي. - اجتياز اختبار الميول الإبداعية والتفوق اللغوي.

جدول (1)

يوضح التجانس بين أطفال المجموعة التجريبية بالقياسين القبلي و البعدي من حيث العمر الزمني و نسبة

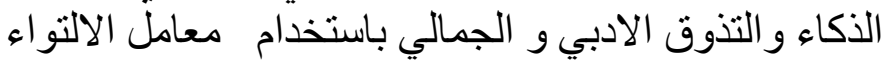

\begin{tabular}{|c|c|c|c|}
\hline معامل الالتو اء & الاحر اف المعيارى & المتوسط & المتغير ات \\
\hline$\cdot r \cdot$ & .0 & $7 . \leq 0$ & ا ـ العمر الزمني \\
\hline.$M$ & $1 . \wedge$ & $11 \varepsilon .0 \mathrm{~V}$ & r ـ نسبة الذكاء \\
\hline$\because \cdot \mu_{-}$ & $1.1 \varepsilon$ & r... & זـ التذوق الادبي \\
\hline
\end{tabular}

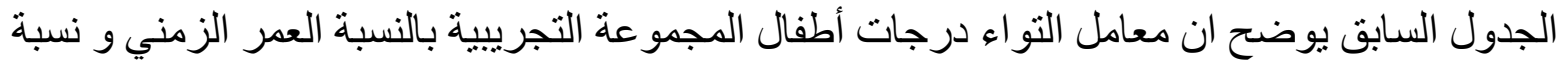

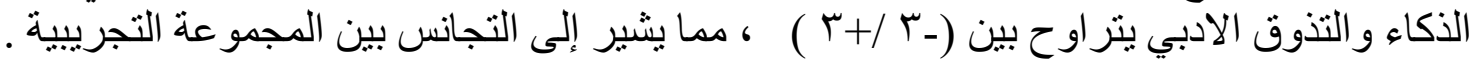

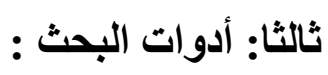

| - اختبار ذكاء الأطفال إعداد (إجلال سري) : قامت الباحثة باستخدام هذا الاختبار لحساب مؤشر الذكاء للاطفال . مبررات اختيار المقياس :

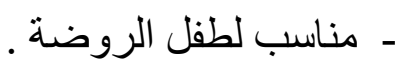
- - ل - له معاملات صدق وثبات عالية. - سهولة تطبيقه ، و تقدير نسبة الذكاء بيسر كما يلي : أـ تقدير الدرجة الخام و هي ( مجموع الدرجات الصحيحة التي حصل عليها الطفل في الاختبار بجزأيه اللفظي و المصور ) ) بـ استخر اج العمر العقلي المقابل للارجة الخام من جدول معايير الأعمار العقلية. . 
ج- تحسب نسبة الذكاء بالمعادلة النالية :

$$
\text { نسبة الذكاء = }
$$

المعاملات الإحصائية لمقياس إجلال سري للأكاء : تم حساب صدق و ثبات المقياس كما يلي :

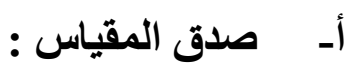

ـ استخدمت إجلال سري صدق المحك باستخدام مقياس ستنافورد بينيه للذكاء ، و كان معامل الصدق

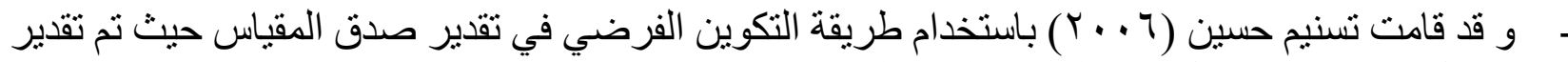

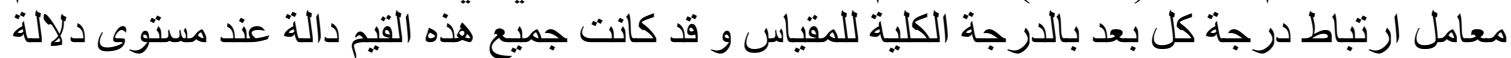

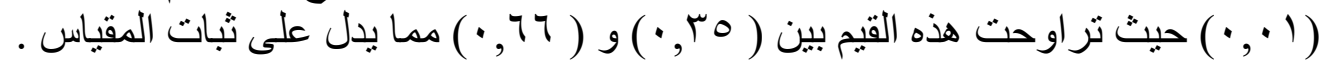

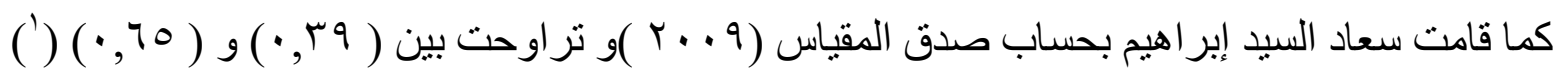

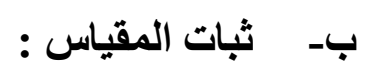

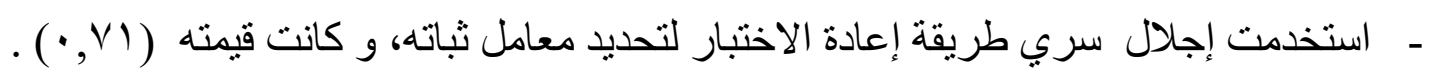

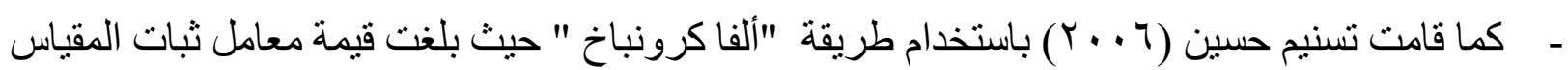

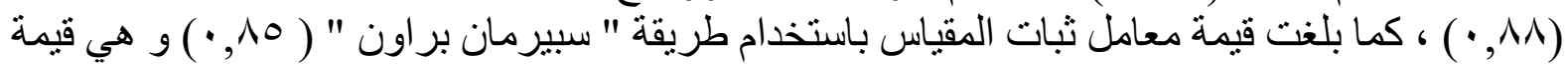

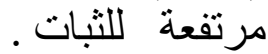

ـ كما قامت سعاد السيد إبر اهيم بحساب ثبات المقياس (9 . . . ) )و تراوحت بين (

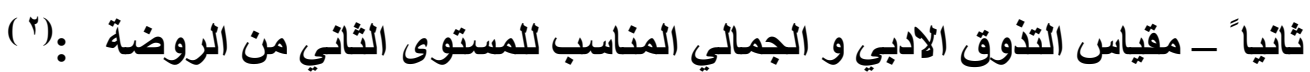

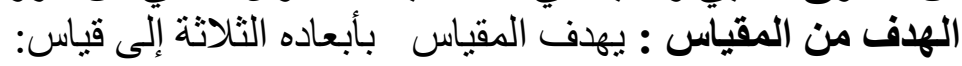

قدرة أطفال الروضة من المستوى الثاني من سن ( 7 - A ) سنوات على تذوق بعض المهار ات الأدبية المقصود تتميتها لديهم من خلال تقديم الأناثيد ، أو النماذج الثعرية المختارة التي الشتمل عليها البرنامج المقترح.

\section{خطوات تصميم المقياس :}

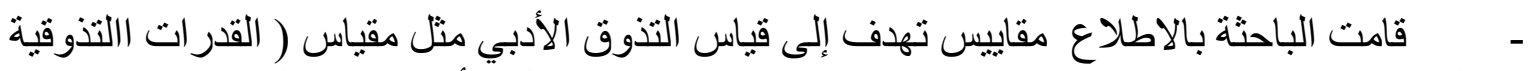

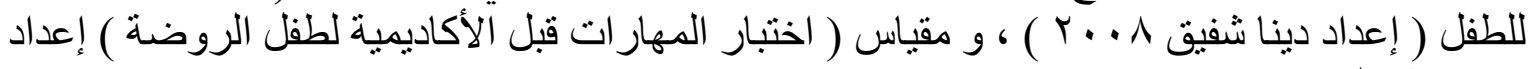

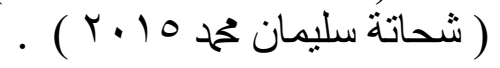

بالاطلاع على البحوث و الدر اسات السابقة فى مجال الدراسة ، و المر اجع العربية و الأجنبية.

إعداد المقياس التذوق الادبي و الجمالي للطفل ، بحيث يكون كل قسم مناسب لطفل الروضة .

1 سعاد السيد إبر اهيم ( 9 ( . ب ) فاعلية برنامج قصص حركية في تتمية الوعي الثقافي لطفل الروضة، المؤتمر الدولي

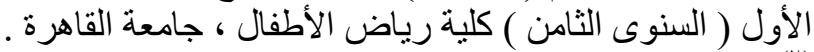

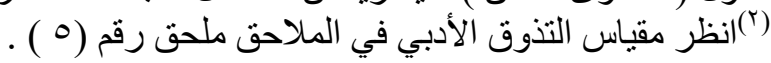


تحديد طريقة القياس بطريقة فردية لكل طفل .

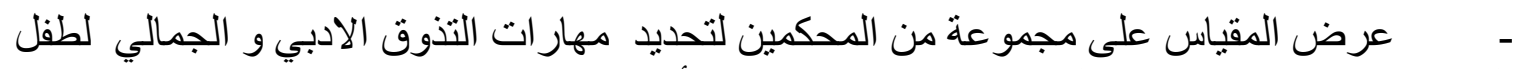

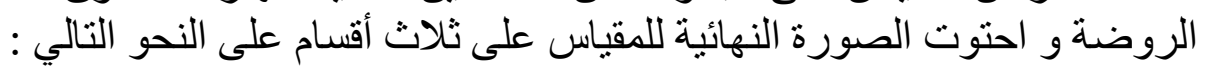
جدول رقم (r) يوضح أقسام المقياس : (بام

\begin{tabular}{|c|c|}
\hline ملاحظات يرى المحكمون إضافتها: & أققسام المقياس \\
\hline & نماذج لأناشيد الأطفال + تدريبات \\
\hline & نماذج لقصص الأطفال + تدريبات \\
\hline & نماذج للقصة الموسيقية الحركية + تدريبات \\
\hline
\end{tabular}
و قد راعت الباحثة عند صياغتها للأسئلة ما يلي:

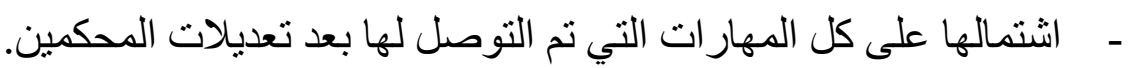

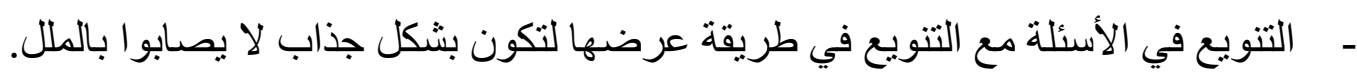

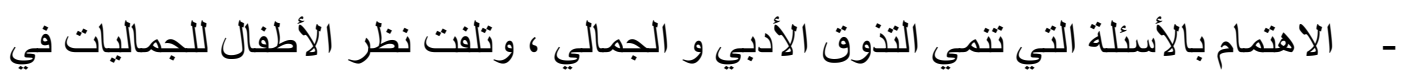

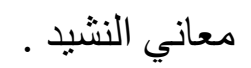

$$
\begin{aligned}
& \text { و قد تكون اختبار التذوق الادبي و الجمالي من ( بr ) سؤ الا موزعين كالآتي : }
\end{aligned}
$$

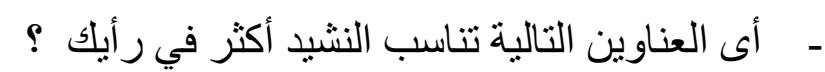

$$
\begin{aligned}
& \text { - الاختيار من متعدد ( ضع خطاء تحت الكلمة الصحيحة مما بين الأقو اس ) . }
\end{aligned}
$$

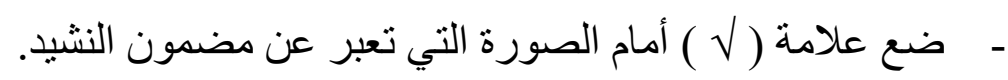

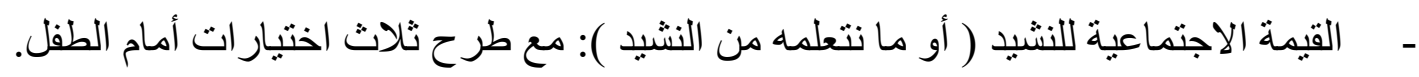

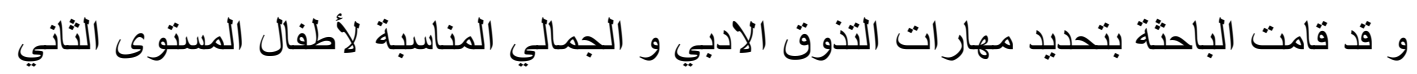

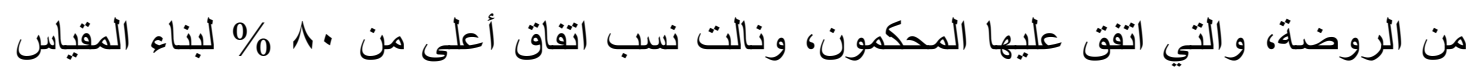
استناداء إلبها. ثم قامت بوضع أسئلة لقياس هذه المهارات في المقياس ( الأناشيد، القصة السمعية، والقصة

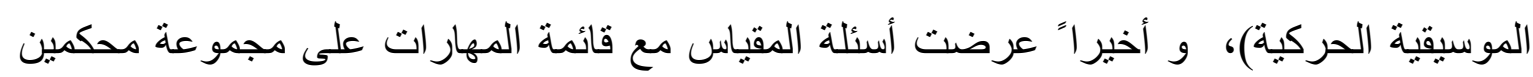
متخصصين ، و الجدول التالي يوضح النسبة المئوية لاتفاق آراء المحكمين على على عبار التهات المقياس

$$
\begin{aligned}
& \text { جدول رقم (r) } \\
& \text { بأقسامه الثلاث : }
\end{aligned}
$$

\begin{tabular}{|c|c|}
\hline | لنسبة المئوية & أققسام المقياس \\
\hline$\% 1 \ldots$ & نماذج لأناثشيد الأطفال + أنشطة لغوية و موسيقية و غنائية \\
\hline$\% 1 \cdots$ & نماذج لقصص الأطفال + أنشطة لغوية و موسيقية و حركية \\
\hline$\% 9 \mathrm{Y}$ & نموذج للقصة الموسيقية الحركية + أنشطة لغوية و موسيقية و حركية \\
\hline
\end{tabular}

يوضح النسبة المئوية لاتفاق آراء المحكمين على أقسام المقياس

و قد اتفق السادة المحكمين بعض التعديلات التي نفذتها الباحثة كالآتي : 
أجمع (1/) من المحكمين على عدم مناسبة القصة رقم (Y) من القسم الثاني لكونها غير معبرة عن

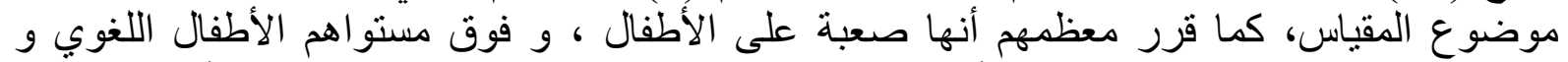

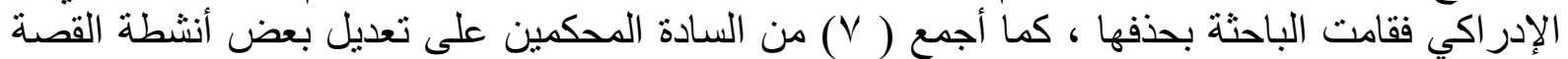

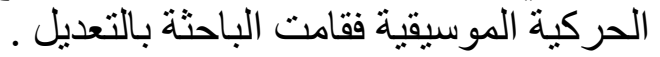

\section{ج- زمن تطبيق المقياس :}

قامت الباحثة بتحديد (ع ا ) دقيقة لكل طفل للإجابة عن أسئلة كل قسم من المقياس ،و ذلك حسب متوسط

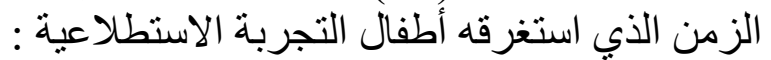

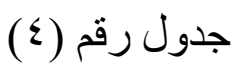

تحديد الزمن المناسب للإجابة على أقسام المقياس

\begin{tabular}{|c|c|c|c|c|c|}
\hline المقياس المناسب & لإججابة عن أسئ الزمن & ليالجابة عن & كل أقسام الزما & متوسط زمن من & أقسـام المقياس \\
\hline دقيقة & الزمن بالثو اني & بالدقائق الزن & بالثو اني & بالدقائق & \\
\hline & & & r اثثانية & 10 & الأناثيد \\
\hline ؟ ـ دقيقة & 9 ه ثانية & ؟ ـ دقيقة & V ثانية & 7 ا دقيقة & القصة السمعبة \\
\hline & & & • اثواني & سا دقيقة & القصة|الموسيقية الحركية \\
\hline
\end{tabular}

د- تصحيح المقياس :

ثناث درجات للاختيار الصحيح الأكثرتعبير ا” عن الموقف المصور.

درجتان عن الاختيار الأقل تعبيراً عن الموقف المصور.

درجة واحدة عن الاختيار غير المناسب و الغير معبر عن الموقف المصور.

و بذللك تكون الدرجة الكلية (r) درجات لكل موقف مصور.

المعاملات الإحصائية لمقياس التذوق الادبي و الجمالي لطقل الروضة :

صدق الاتساق الداخلي:

قامت الباحثة بإيجاد صدق الاتساق الداخلي للمقياس، وذللك باتباعها لعدة خطو ات لازمة للتأكد من إتساق

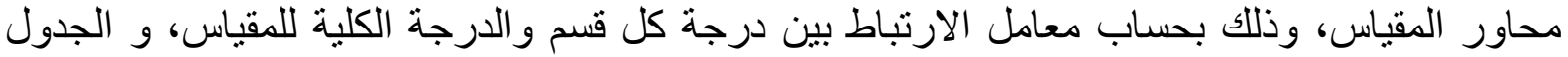

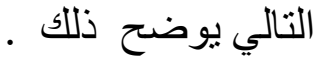


جدول رقم (0) - (0)

جدول يوضح معامل الارنباط بين درجة كل محور و الدرجة الكلية للمقياس

\begin{tabular}{|c|c|c|}
\hline مستوى الدلالة & معامل الصدق & محاور المقياس \\
\hline دال عند ا .. & $\cdot .7 \cdot \varepsilon$ & ا ـ المحور الأول \\
\hline دال عند ا •. & $.0 \leq 7$ & r- المحور الثناني \\
\hline دال عند ا •. & $.0 . \varepsilon$ & rـــ القسم الثالث \\
\hline دال عند ا •. & $.0 Y \leq$ & ا ـ المحور الرابع \\
\hline
\end{tabular}

ويتضح من الجدول السابق أن معاملات ارتباط درجات أقسام المقياس بالدرجة الكلية دالة

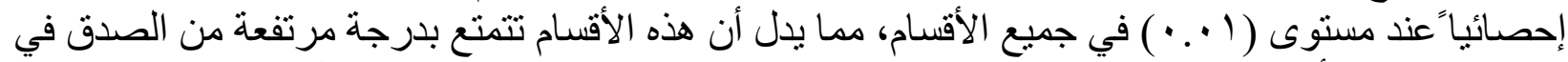

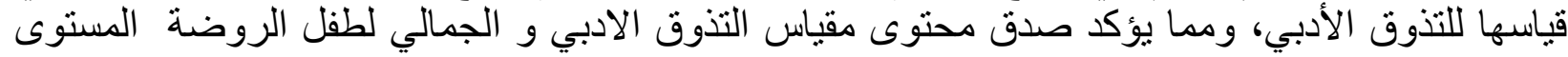
آثي ثبات المقياس :

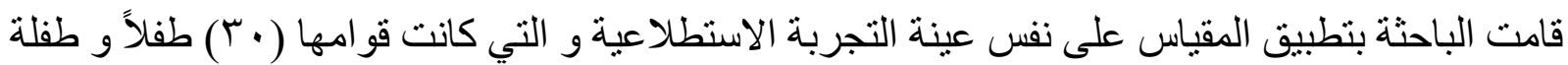

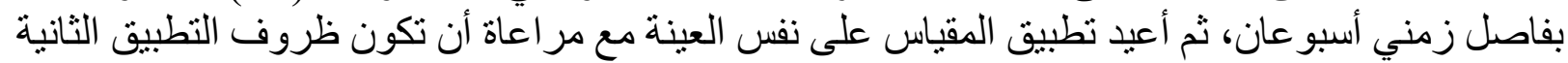

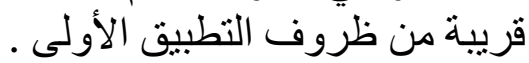
وقد قامت الباحثة بحساب المتوسطات والانحر افات المعيارية لدرجات القياس القبلى والقياس البعدى، ثم ثمثي

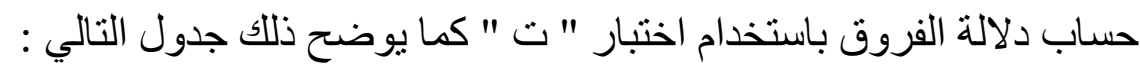

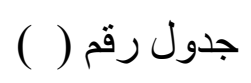

يوضح الفروق بين التطبيق واعادة التطبيق لمقياس التذوق الادبي و الجمالي لدي العينة الاستطلاعية

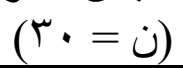

\begin{tabular}{|c|c|c|c|c|c|}
\hline الدلادة & قيمة ت & المتورقين بين & المعياري & المتوسط & مقياس التذوقي الادبي و \\
\hline \multirow{2}{*}{ غير د } & \multirow{2}{*}{$1.0 \leqslant V$} & \multirow{2}{*}{$\cdot r V$} &.$V T$ & 11. & التطبيق الأول \\
\hline & & & .0. & $11 . r \mu$ & التطبيق الثانى \\
\hline
\end{tabular}

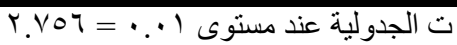

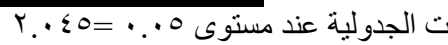

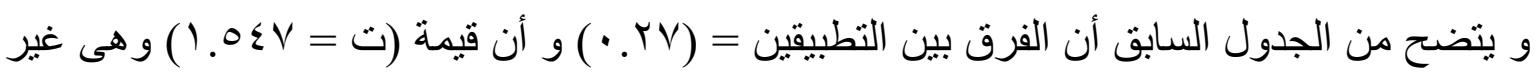

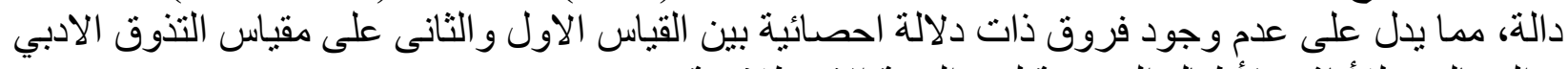
و الجمالي للأناثيد لأطفال الروضة لدي لدي العينة الاستطلاعية.

الباحثة) قائم على الفنون التعبيرية لتنمية التذوق الادبي و الجمالي لاى أطفال الروضة : ( إعداد

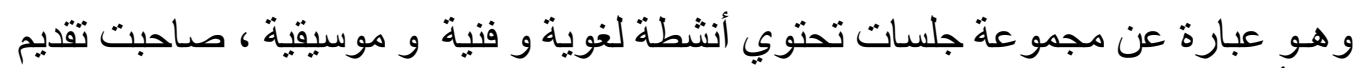

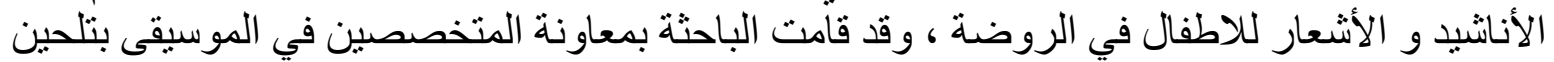

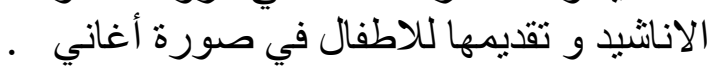




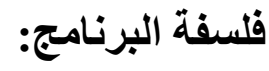

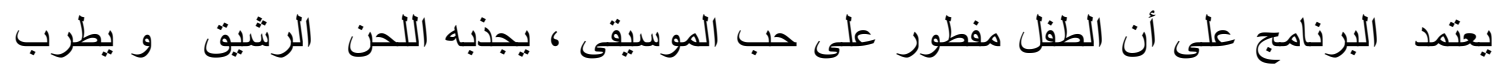

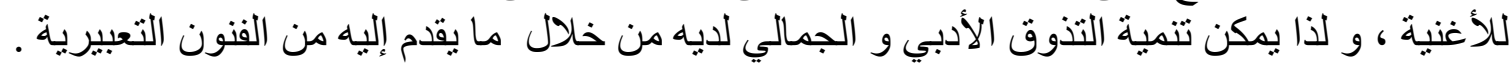

أسس و معاييز بناء البرنامج:

بالرجوع للإطار النظري للار اسة الحالية، و البحوث و الدراسات السابقة ، نوصلت الباحثة للأسس التالية في بناء البرنامج و يمكن تلخيصها في النقاط النالئة النالية:

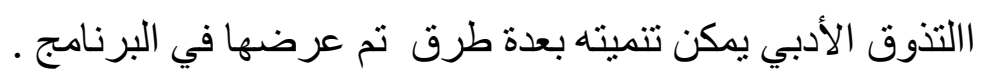

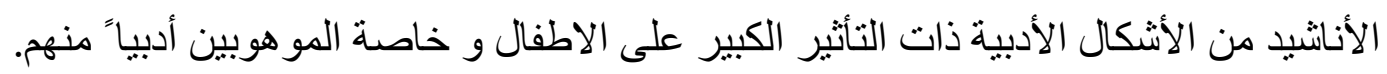

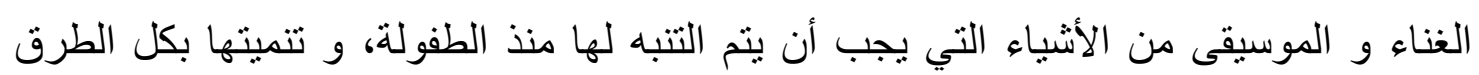
الممكنة

الأهداف التربوية للبرنامج: يهدف البرنامج لتحقيق الأهداف التالية : أن يتعرف الطفل الموهوب أدبياً على أنثكال ادبية متنو عة متمثلة في أناثيد جلسات البرنامج.

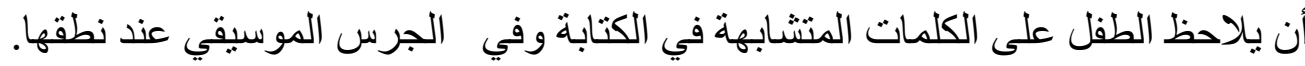

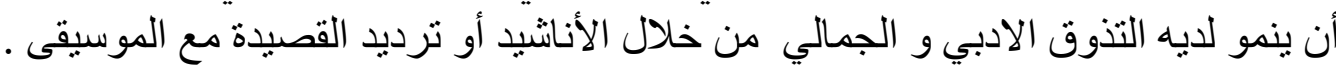

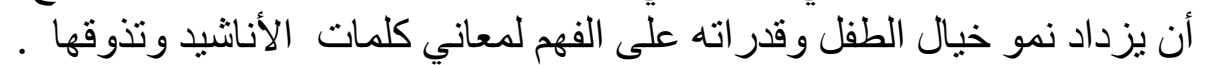

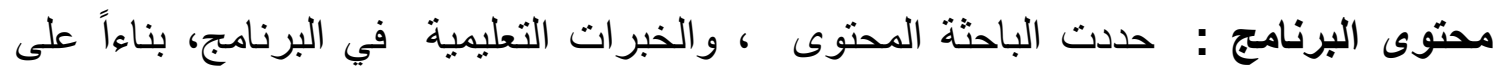

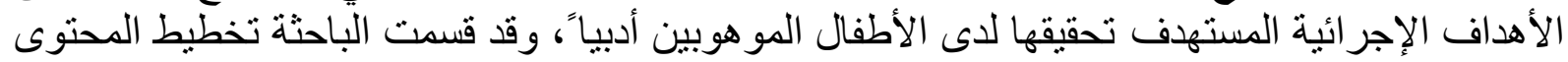

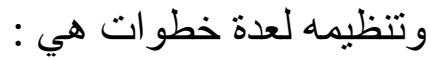

الاطلاع على الأنشطة المقررة على رياض الأطفال و اشتقاق ما يتناسب منها مع البرنامج الحالي

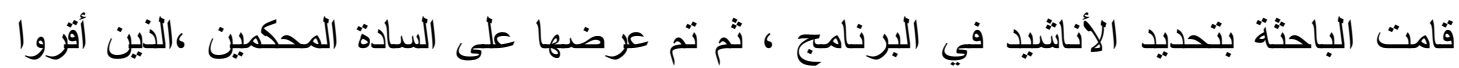

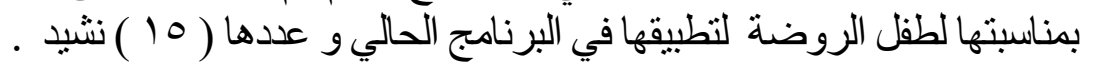

تحديد مهارات التذوق الادبي و الجمالي التى تم معالجتها في البرنامج والزمن المخصص لتطبيقها. تحديد الأنشطة الموسيقيةو الغنائية و اللغوية المصاحبة لكل نشيد لتحقق أهداف البحث . التنسيق مع إدارة الروضة لتطبيق جلسات البرنامج ـ أنشطة البرنامج المصاحبة لتقديم الأناشيد في البرنامج : قامت الباحثة للتخطيط للأنشطة الدصاحبة لتقديم الأنانثيد لإثراء ثروة الأطفال اللغوية ، و قد

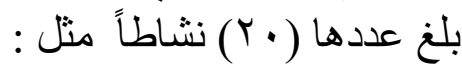


نشاط لغوي ينمي التذوق الادبي و الجمالي و تعليم الأطفال كتابةالأناثيد بعنوان [ لعبة استخرج

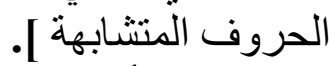
نشاط تذوق أدبي : يهدف للفت انتباه الأطفال لفن الوصف في النشيد بطريقة مبسطة.

نشاط لغوي ينمي التذوق الادبي و الجمالي للاطفال من خلال نشاط بعنوان: (معنى النشيد )

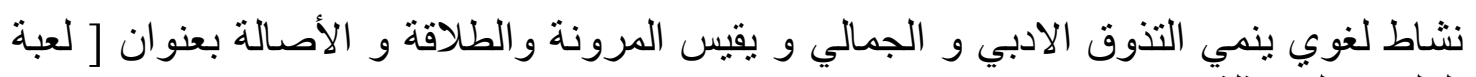

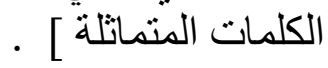
ثانياً: الأنشطة الفنية مثل : • نشاط فني بعنو ان ( ارسم و عبر) لرسم بعض شخصيات الأناشيد مثل رسم الثخصية بطلة الأناشيد

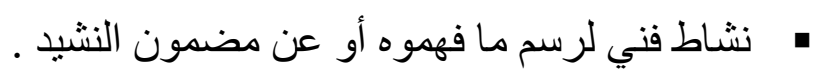

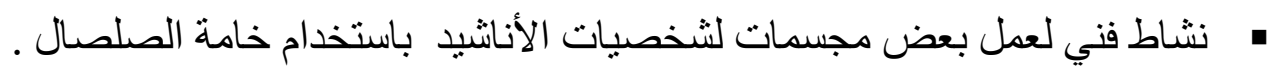

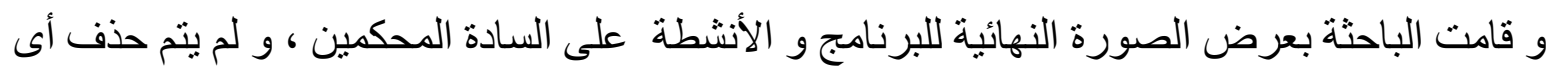
نثاط ، و الجدول التالي يوضح نسبة اتفاق السادة الدحكمين على تللك الأنشطة :

\begin{tabular}{|c|c|c|}
\hline النسبة الدئوية لاتفاق السادة المحكمين & نوع النشاط & م \\
\hline$\% 1 \ldots$ & أنشطة لغوية & 1 \\
\hline$\% 1 \ldots$ & أنثطة فنية & r \\
\hline$\% 1 \ldots$ & أنثطة موسيقية & $r$ \\
\hline
\end{tabular}

و فيما يلي جزء من جلسة من جلسات البرنامج بعنوان نشيد الفراشات :

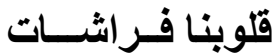

$$
\begin{aligned}
& \text { ضحكـاتنا فراشـات } \\
& \text { وكل مــا في وطـني } \\
& \text { من سندس وسوسن } \\
& \text { يرقـ كالفراشـات } \\
& \text { يمرح كالفر اثــــات } \\
& \text { جميــلة مثـل الفرح }
\end{aligned}
$$

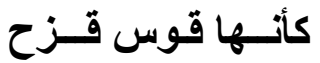

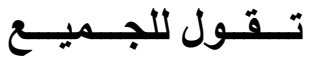

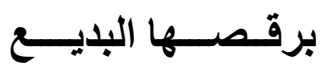

$$
\begin{aligned}
& \text { ما أجــمل الحيـــــاة ! }
\end{aligned}
$$




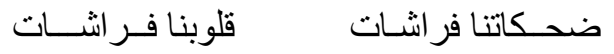
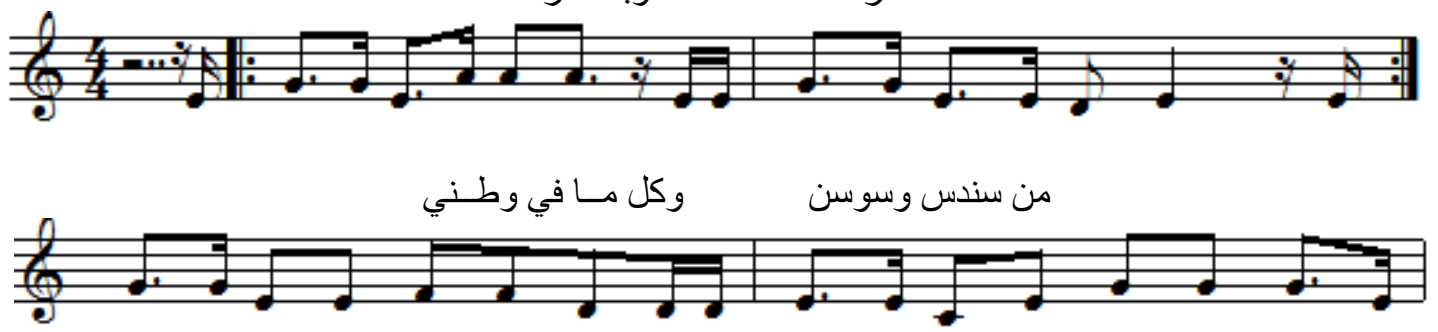

$$
\text { من سندس وسوسن وكل مـا في وطـني }
$$

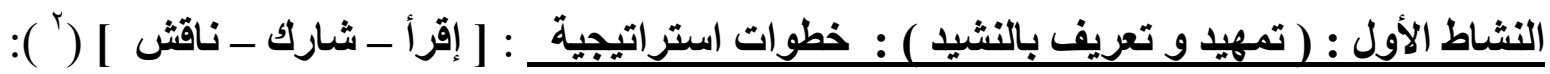

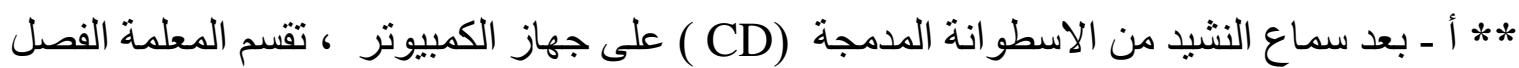

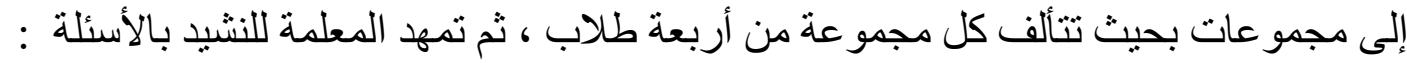

*- عن أى شىء يتحدث الثاعر في النشيد ؟ من يضع عنوانا آخر للنشيد يعبر عما جاء فيه ؟ * هل تحب الفر اثنات ؟ صف لنا الفر اشة .

بـ بعد سماع النشيد ، بطر ح كل طالب في المجمو عة سؤ الا على زميله ( مر ادف كلمة ، مضاد كلمة

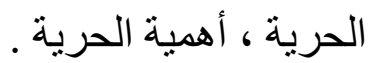

ج- يتناقش أفر اد المجموعة للوصول للإجابة ثم يشارك طفل من الهمو عة بالإجابة . النشاط الثانى (نثاط لغوي ) : ( أكمل الناقص ) عن طريق المجموعات و التعلم التعاونى : يهذف هذا النشاط لتحقيق الهذف التعليمي التالي : أـ لفت انتباه الأطفال لجمال الطبيعة من حولنا ووجوب المحافظة عليها . الأسئلة : - - أكمل الناقص من النشيد:

$$
\begin{aligned}
& \text { قلوبنـا فـر اشـــات } \\
& \text { ضحكاتنا } \\
& \text { وكل مـا في ......... } \\
& \text { من ......... وسوسن } \\
& \text { يرقـ كالفراشـات }
\end{aligned}
$$$$
\text { ץ- بم وصف الثاعر القلوب ؟ ولماذا؟ ــ }
$$

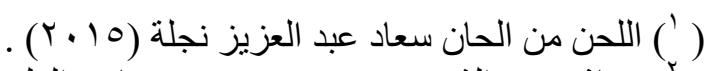

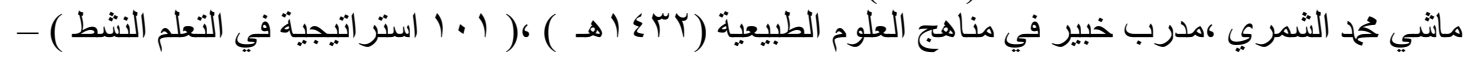

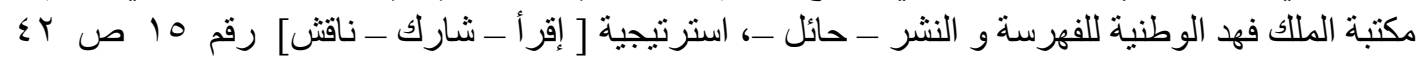




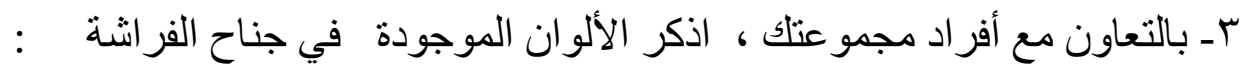

\section{النشاط الثالث : (تذوق أدبى) :}

يهدف هذا النشاط لتحقيق الأهداف التعليمية التالية :

تعريف الأطفال بفن الوصف في النشيد بطريقة مبسطة .

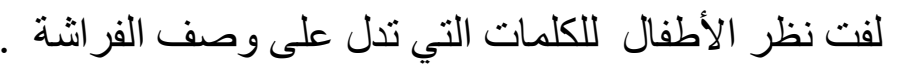

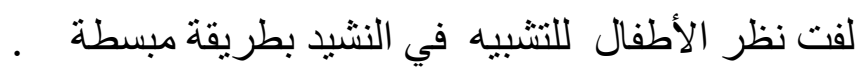

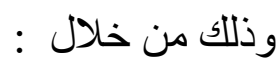

1 - تقسيم الأطفال إلى مجمو عتين وكل مجموعة تتخذ لها اسماً و ترسم الباحثة في جانب السبورة

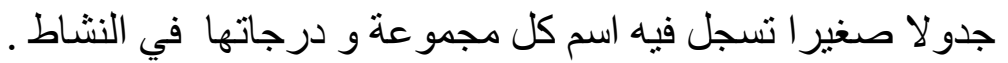

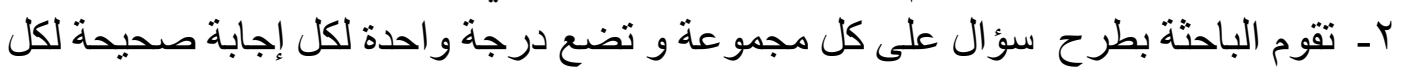

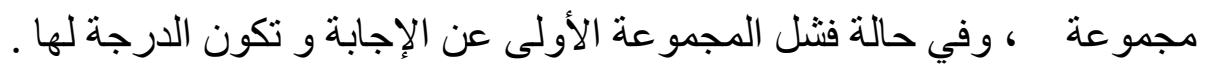
الأسئلة : الأبرة

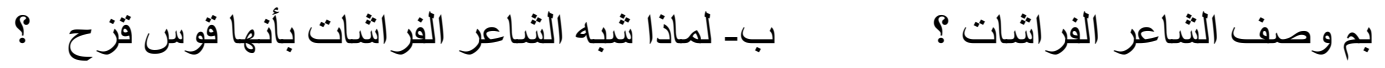
تقويم البرنامج : و انقسم التقويم لثثلاث مراحل :

أـ تقويم قبل البرنامج ، و تمثل ذللك في تطبيق مقياس التذوق الأدبي و الجمالي للطفل . بـ التقويم المصاحب : و هو تقويم مستمر منذ بداية البرنامج و حتى نهايته ، و ينم من خلال : - ملاحظة سلوك الطفل أثناء الجلسات و تأدية الأنثطة و التعزيز و التشجيع للأطفال .

ج- تقويم بعدي للتعرف على التقدم الذي تحقق بعد تطبيق البرنامج و مقارنته بالتطبيق القبلي .

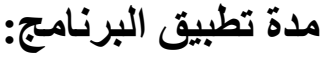

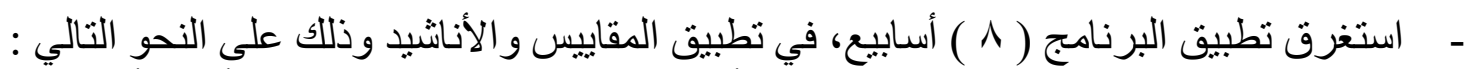

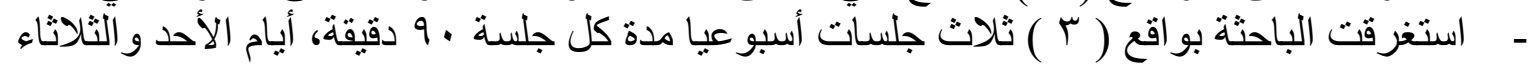
و الخميس من كل أسبوع.

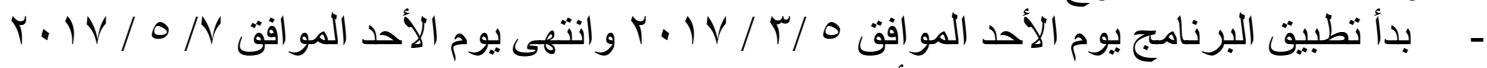

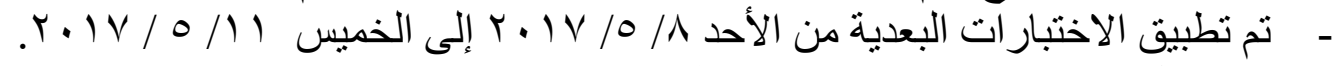
- و الجدول التالي يوضح مو اعيد تتفيذ جلسات البرنامج : 


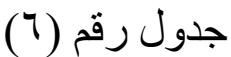

يوضح مو اعيد تنفيذ جلسات البرنامج

\begin{tabular}{|c|c|c|}
\hline الزمن المحدد للتنفيذ & تاريخ تتفيذها & الجلسة \\
\hline فترة در اسية (· 9 دقيقة) & 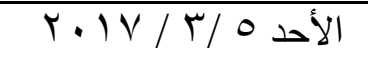 & 1 \\
\hline فترة در اسية (• 9 دقيقة) & 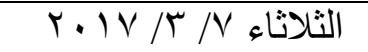 & $r$ \\
\hline فترة در اسية (• 9 دقيقة) & 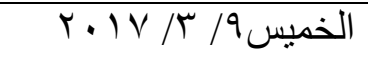 & $r$ \\
\hline فترة در اسية (• 9 دقيقة) & الأحد 12/ T/ V/ T & $\varepsilon$ \\
\hline فترة در اسية (• 9 دقيقة) & 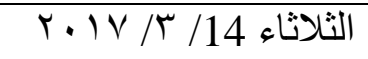 & 0 \\
\hline فترة در اسية (• 9 دقيقة) & الخميس 16/ r/ V V. T & 7 \\
\hline فترة در اسية (• 9 دقيقة) & 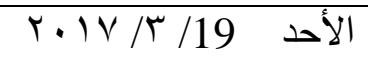 & V \\
\hline فترة در اسية (• 9 دقيقة) & 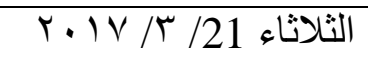 & $\Lambda$ \\
\hline فترة در اسية (، 9 دقيقة) & 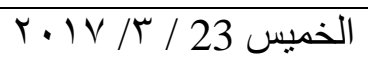 & 9 \\
\hline فترة در اسية (• 9 دقيقة) & الأحد 26/ / / / / T / & 1 . \\
\hline فترة در اسية (• 9 دقيقة) & 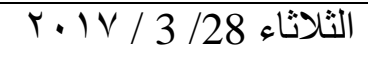 & 11 \\
\hline فترة در اسية (• 9 دقيقة) & 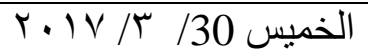 & IT \\
\hline فترة در اسية (• 9 دقيقة) & الأحد / / / / / & 14 \\
\hline فترة در اسية ( • 9 دقيقة) & 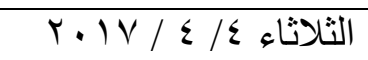 & $1 \varepsilon$ \\
\hline فترة در اسية ( •9 دقيقة) & 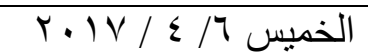 & 10 \\
\hline فترة در اسية (• 9 دقيقة) & الأحد 9 / / / IV & 17 \\
\hline فترة در اسية (• 9 دقيقة) & 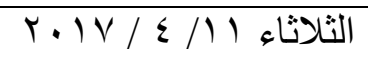 & IV \\
\hline فترة در اسية ( •9 دقيقة) & 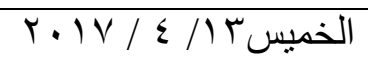 & 11 \\
\hline فترة در اسية ( •9 دقيقة) & 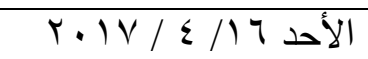 & 19 \\
\hline فترة در اسية (• 9 دقيقة) & 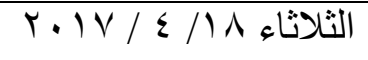 & $r \cdot$ \\
\hline فترة در اسية (• 9 دقيقة) & 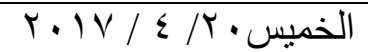 & YI \\
\hline فترة در اسية (• 9 دقيقة) & الأحد r/K/ / / IV & TY \\
\hline
\end{tabular}




\begin{tabular}{|c|c|c|}
\hline الزمن المحدد للتنفيذ & تاريخ تنفيذها & الجلسة \\
\hline فترة در اسية (، 9 دقيقة) & 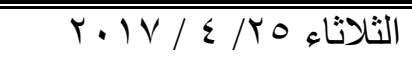 & rT \\
\hline فترة در اسية ( • 9 دقيقة) & 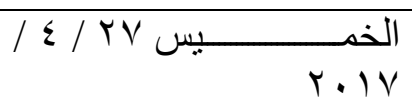 & TE \\
\hline فترة در اسية (· 9 دقيقة) & 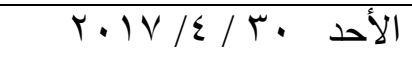 & ro \\
\hline فترة در اسية (· 9 دقيقة) & 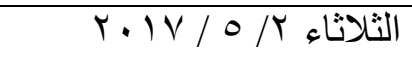 & rT \\
\hline فترة در اسية (• 9 دقيقة) & 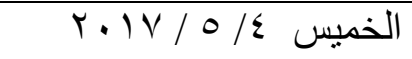 & TV \\
\hline فترة در اسية ( • 9 دقيقة) & 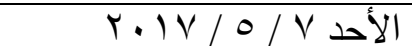 & rᄉ \\
\hline
\end{tabular}

استخدمت الباحثة الإحصائيات التالية في معالجة البيانات :

الأسلوب الإحصائي المستخدم :

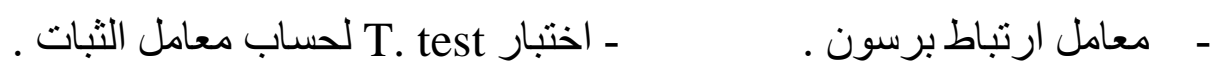

- اختبار T. test لحساب دلالة الفروق بين المتوسطات .

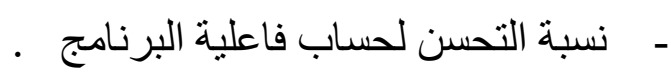

عرض النتائج و تفسيرها :

$$
\text { الفرض الأول : الفي }
$$

1) والذى ينص على(توجد فروق ذات دلالة إحصائية بين منوسطي درجات القياس القبلى و القياس

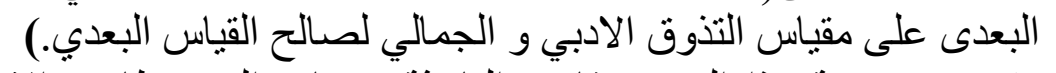

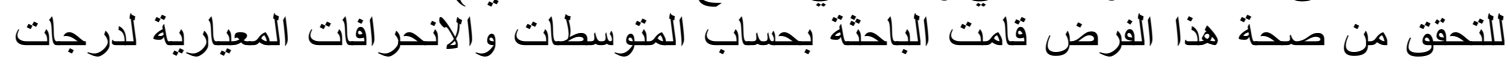
القياس القبلى و القياس البعدى، و حساب دلالة الفروق باستخدام اختبار " ت " T. test ،كما الجدول

درجات القياس القبلي و البعدي لمحاور مقياس التذوق الأدبي و الجمالي للأطفال

$$
\text { جدول رقم (V) }
$$

\begin{tabular}{|c|c|c|c|c|c|c|}
\hline \multirow[b]{2}{*}{ مستوى الدلالة } & \multirow[b]{2}{*}{ "قيمة " } & \multicolumn{2}{|c|}{ القياس البعدي } & \multicolumn{2}{|c|}{ القياس القبلي } & \multirow{3}{*}{ التذوق الأدبى مقباس } \\
\hline & & الانحر اف المعيارى & المتوسط & الانحر اف المعيارى & المتوسط & \\
\hline 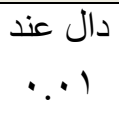 & $V .1 \leqslant 0$ & $.0 \leqslant$ & 11.17 &.$\wedge$. & $1 \cdot . \leqslant V$ & \\
\hline
\end{tabular}

دلالة الفروق بين متوسطى درجات القياس القبلى و القياس البعدى ردو

$$
\text { على مقياس التذوق الأدبى (ن = • ب ) ) }
$$

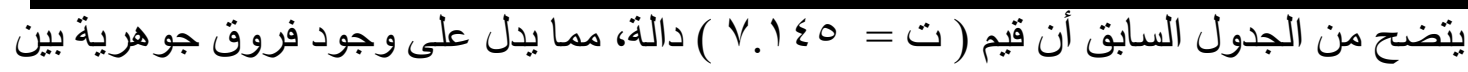

القياس القبلى و القياس البعدى على مقياس التذوق الأدبى، مما يدل على فاعلية البرنامج الغنائى فى تنمية

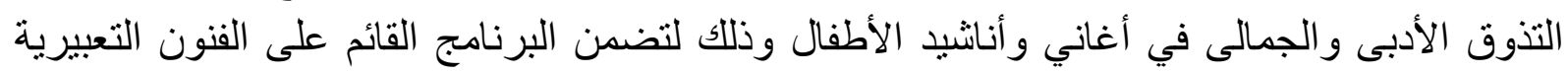


لتنمية التذوق الأدبي والجمالي لطفل الروضة على انشطة واساليب تركيز مختلفة قامت بتنمية الخيال

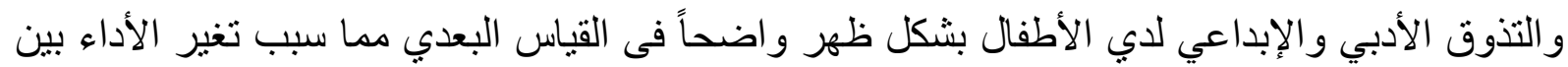

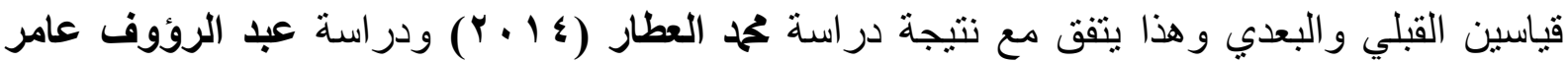

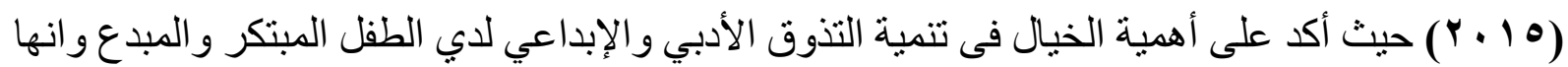

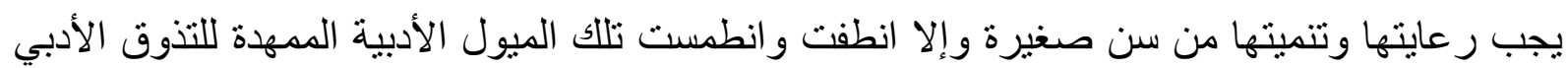
و والجمالي.

( لفرض الثاني : ذات دلالة إحصائية بين متوسطي درجات الذكور ودرجات الإناث على مقياس

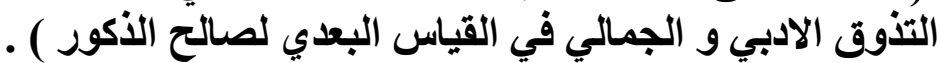

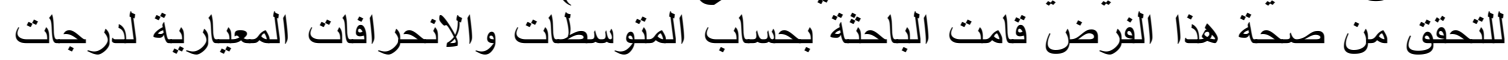

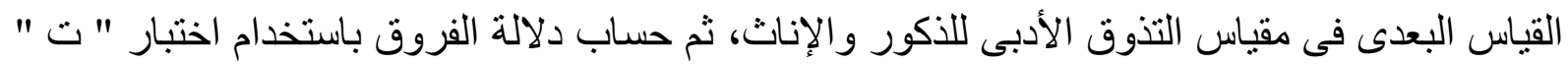
T. test

$$
\text { جدول رقم ( } 1 \text { ( ) }
$$

دلالة الفروق بين متوسطى درجات الذكور ودرجات الإناث فى القياس البعدى (لإى

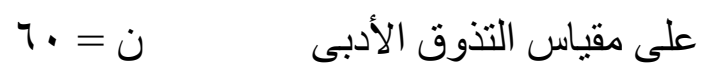

\begin{tabular}{|c|c|c|c|c|c|c|}
\hline \multirow{2}{*}{ مسنوى } & \multirow{2}{*}{ "ت " قيمة } & \multicolumn{2}{|c|}{$\begin{array}{l}\text { الإناث } \\
\\
\end{array}$} & \multicolumn{2}{|c|}{ 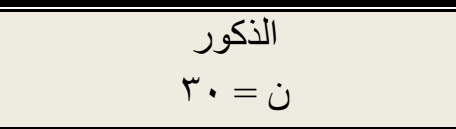 } & \\
\hline & & الانحر اف المعيارى & المتوسط & الانحر اف المعيارى & المتوسط & \\
\hline غير دال & $\because .1 \%$. &. $.0 Y$ & $11 . Y V$ &. $.0 \mathrm{~V}$ & 11.10 & مقياس التذوق الأدبى \\
\hline
\end{tabular}

هذا الفرض غير دال (لم تتحقق الدلالة بين الذكور الإناث فى القياس البعدى / المتوسطات متساوية) مما

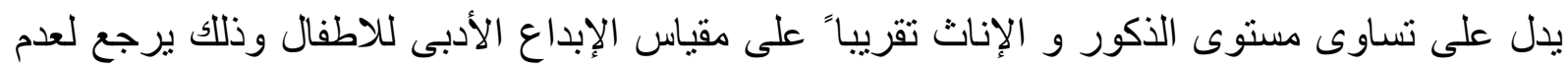

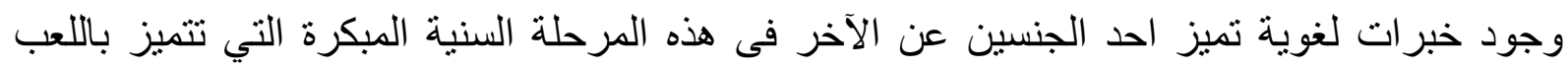
الإيهامي و التخيلي بحيث لا يظهر دلالة إحصائية في هذه السن الصغير الصيرة.

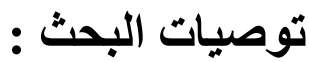

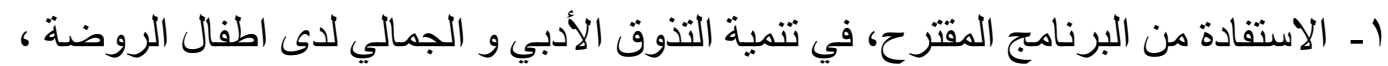

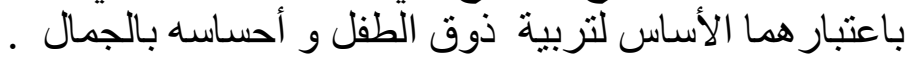
r- ضرورة تفعيل الأنثطة اللغوية و الفنية مع تقديم الأنانثيد للأطفال كل يوم، و تنمي لديهم قدرات و

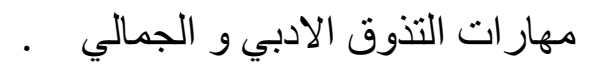
r- ضرورة الاهتمام بتدريس اللغة العربية بجدية في كليات رياض الأطفال لتخريج معلمة مثققة. 


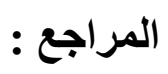

\section{أولاً : المراجع العربية :}

ا ـ يوسف عبد القادر رشيد (0 . ب ) ) : أثر الموسيقى في تعليم اللغة العربية للأطفال ، الرياض، شركة العبيكان ط ، ،ص VI

Y- إبر اهيم أنيس (1999 ) ): موسيقى الثعر ، القاهرة ، مكتبة الأنجلو الأمريكية، طץ ، ص 19

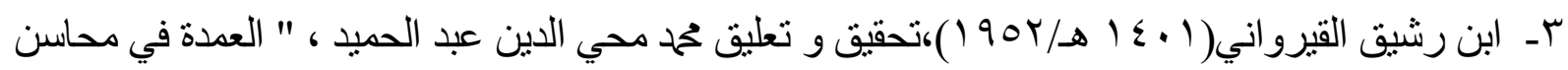

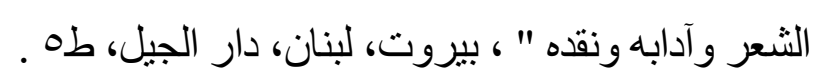

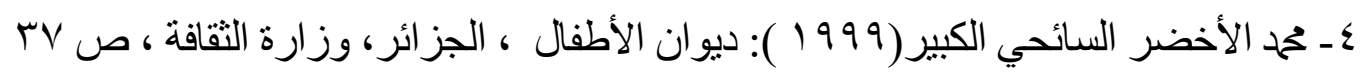

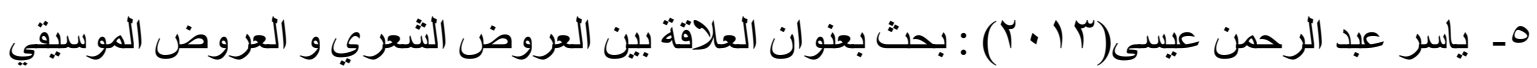

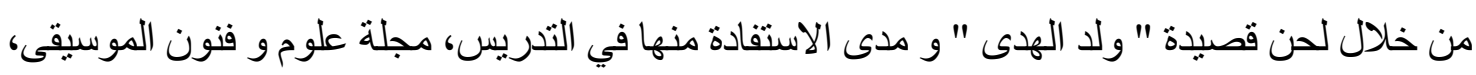

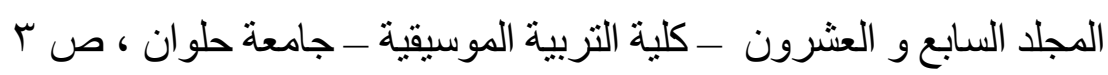

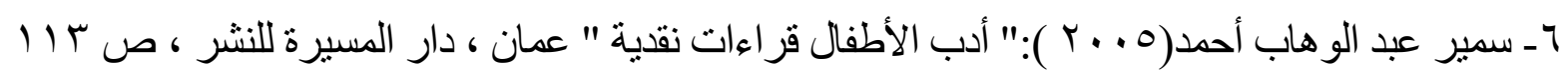

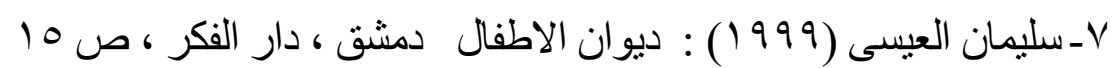

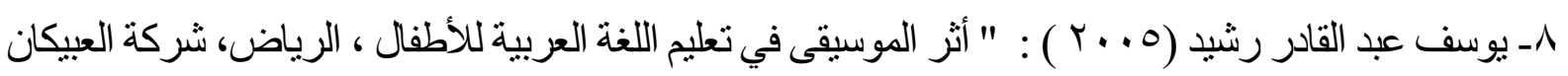

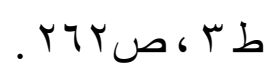

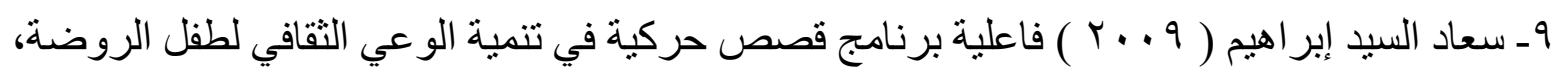

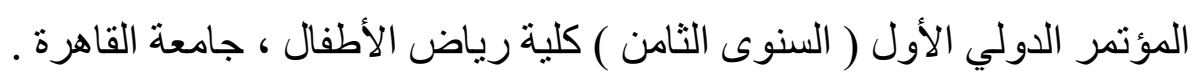

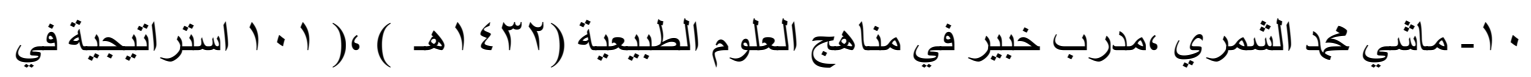

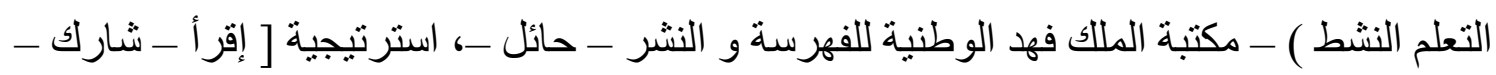

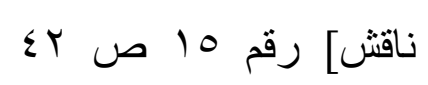

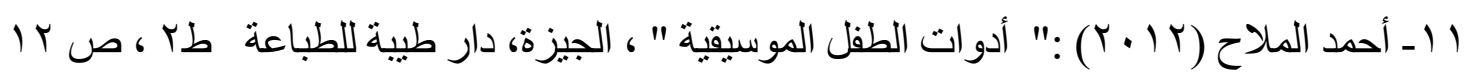

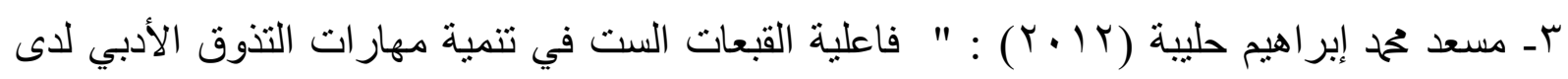

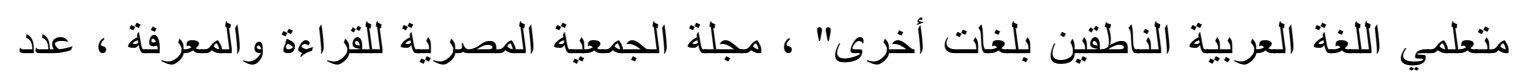

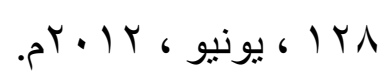

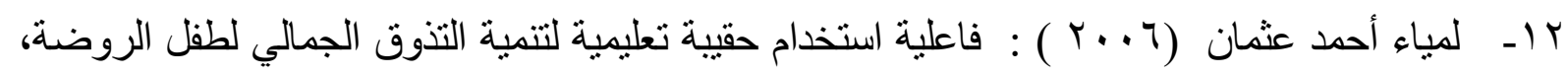
رسالة ماجستير - كلية رياض الأطفال - جامعة الاسكندرية. 
ب ا ـ مها إبر اهيم غانم (9 . . r ) :" أدب الأطفال عند عبد التو اب يوسف " ، القاهرة ، الدار المصرية اللبنانية

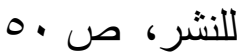

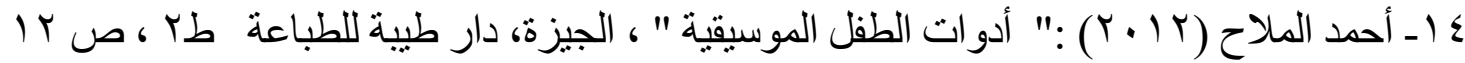

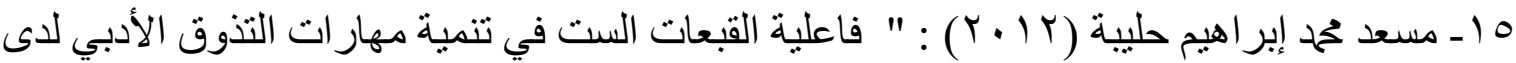
متعلمي اللغة العربية الناطقين بلغات أخرى" ، مجلة الجمعية المصرية للقر اعة و المعرفة ، عدد 1

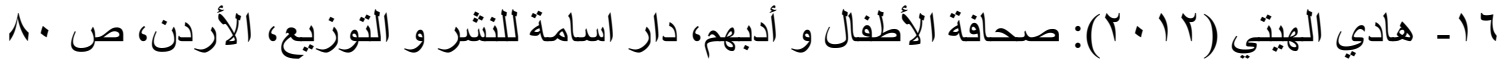
V ا ـ دينا عوض عحم(T ( Y ):فاعلية برنامج قائم على بعض الأشكال الأدبية لزيادة الاستجابة العلاجية لاى الاطفال مرضى السرطان، ماجستير، قسم العلوم الأساسية، كلية الطفولة المبكرة، جامعة

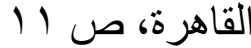

1 ـ ـ أحمد زلط ( 9 . . Y ) : " الاتجاهات الحديثة لأدب الطفل " ، القاهرة، دار هبة النيل للنشر و التوزيع ،

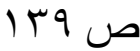
1. ثانياً المراجع الأجنبـ

19- Alexander Mary , E.D.D( 1983) : The Influence of Rythming Vrses on Young Children Ability to Repeat Rhythmic Phrases, North Texas State University , p. 30

20- Elzegiely In , Gelpi Elsa(1996) : The Enjoyment of Literature Paper , Given at the third Annual Tsol Convention Chicago, Illinois, March , Ch. 5-8, P 12

21- Ford Micheal(2004) : Childrens Literature Art Activities, Art Education ,Poetry, Americans , New York , v 21, p 41- 43

22- Roberts - John, : Teaching Meter (1989) ,Why and How ? Paper Presented at the Annual Meeting of the National Conical of Teachers of English , $69^{\text {th }}$,son Francisco 22-24 ( p . 28 ) 